\title{
Mística y naturalismo. Pablo de Rojas, San Juan de la Cruz y el Nazareno de los Mártires de Granada ${ }^{1}$
}

\author{
Juan Jesús López-Guadalupe Muñoz *
}

La identificación de la imagen de Jesús Nazareno del antiguo convento de los Mártires de Granada nos introduce en el análisis del proceso de avance hacia el naturalismo en la escultura andaluza, la influencia de la mística (sobre todo San Juan de la Cruz) y de las circunstancias históricas, y la peculiar evolución del tipo iconográfico de Cristo con la cruz a cuestas. Su importancia estriba en que de aqui parte la escultura procesional andaluza.

The identification of the Nazarene Jesus's image of the old convent named Martyrs of Granada introduce us in the analysis of the process of advance towards the naturalism in the andalusian sculpture, the influence of the mystic (over all San Juan de la Cruz) and the historical circunstances, and the peculiar evolution of iconographic type of Christ carrying the cross on his aun back. Its importance is based on that it's the begining of the andalusian processional sculpture.

A la memoria del profesor José Szmolka Clares

Pudieran parecer sin relación, si no es que opuestos, los conceptos que encabezan estas líneas. El análisis de la realidad contingente, la comprensión de los modelos que ofrece la Naturaleza frente a la inmaterialidad de la contemplación espiritual. Sin embargo, estas dos realidades de diversa naturaleza coexisten en el último cuarto del siglo XVI español en una coyuntura sociopolítica de crucial importancia en el devenir del pais. La relación entre el pensamiento místico y el arte barroco constituye un grueso problema que requiere un mínimo de reflexión historiográfica ${ }^{2}$. La crítica ha argüido tradicionalmente ciertos asertos de San Juan de la Cruz referentes a la pertinencia del uso de las imágenes para vincularlo al arte barroco. Ciertamente no es adscribible por su trayectoria vital en el periodo historiográficamente considerado como barroco y, por otro lado, el desapego de lo mundanal y sensible no parece estrechar vínculos con la imagen religiosa. Sin embargo, se deduce claramente de sus escritos la aprobación del uso de las imágenes en la experiencia religiosa: si suponían un peligro o lastre evidente para un movimiento eminentemente espiritual como es la unión mística con Dios, objetivo del creyente según el místico, Juan de Yepes supo aprovechar hábilmente - entroncando con la tradición tomista - el potencial del uso de las imágenes, ahora redefinido como una característica no del Cristianismo sino del Catolicismo. Tanto la tradición de la Iglesia —en oposición al protestantismo- como el incitar a la devoción de los fieles eran benéficos efectos que validaban la imagen devocional.

Pero no es sólo eso. Determinados planteamientos estéticos del Santo de Fontiveros, más o menos explícitos en sus escritos — buena parte de los cuales redacta

LÓPEZ-GUADALUPE MUÑOZ, Juan Jesús, "Mística y naturalismo. Pablo de Rojas, San Juan de la Cruz y el Nazareno de los Mártires de Granada”, en Boletín de Arte, n ${ }^{\text {os }} 26-27$, Universidad de Málaga, 2005-2006, págs. 249-282. 
en Granada - parecen «modelar» un tipo de imagen afín a una religiosidad sincera y profundamente espiritual, en la que la oscilación entre el clasicismo y el naturalismo representa el germen de la definitiva liquidación de los modos expresivos manieristas, aunque abominando algunos de los usos caracteristicos del Barroco como el vestir las imágenes. Sin embargo, el carácter convincente de las mismas, trasunto de la imagen mental proporcionada por la elevación espiritual más que estimulación sensorial, parece abocar a un naturalismo contenido como el de su contemporáneo Pablo de Rojas o, en la generación siguiente, Martínez Montañés, pero nunca al realismo hiriente del pleno barroco que en escultura puedan representar un Gregorio Fernández o un $\mathrm{Pe}$ dro Roldán, por ejemplo. Se trata de un arte íntimamente ligado a la espiritualidad; no es el objetivo la satisfacción sensorial, ni siquiera su estimulación, sino la estimulación y satisfacción espirituales, desde el alma, no desde los sentidos. Para ello, desde luego, se requeria una poco asequible sensibilidad, muy desarrollada y bien formada. La renovación paralela de la experiencia religiosa y de su experiencia artística justifican su atención a las imágenes y hace plausible su vinculación a imágenes concretas como la que aqui se trata, partiendo además de un conocimiento directo de la práctica artística $^{3}$ y de la plástica de su tiempo. Evidentemente, los derroteros posteriores de esta senda artística son bien distintos a los pretendidos por el santo carmelita.

En realidad, aboca al terreno de las complejas relaciones entre idea e imagen y a los desdibujados límites entre apariencia y realidad tan característicos del Barroco. Lo que comporta la espiritualidad mística de imagen mental es lo que probablemente asegura la conexión con la concreción plástica que ofrece la obra de arte devocional y puede entrar a formar parte de los factores que determinan los atisbos de naturalismo que la escultura andaluza de esas décadas presenta de la mano de artistas como el alcalaíno Pablo de Rojas (1549-1611), una de las más tempranas manifestaciones de este cambio estético que caracteriza al pleno barroco. La reciente identificación de la imagen de Jesús Nazareno del desaparecido convento de los Mártires de Granada,

\footnotetext{
* Universidad de Granada.

1 El presente trabajo se integra en el proyecto de investigación BHA2001-3300-C03-01 ("El discurso religioso en el Antiguo Régimen. Dos instrumentos de disciplinamiento social: las misiones y la obra de arte"), financiado por la Dirección General de Investigación del Ministerio de Ciencia y Tecnología.

2 Se trata de una tesis que encuentra sus primeras formulaciones en Werner Weisbach al sostener que la mística se encontraba en la base del sentimiento religioso contrarreformista y de sus plasmaciones plásticas, y que ha sido matizada por otros estudiosos, llegando a lo excesivo de las apreciaciones de Victor I. Stoichita al considerarlo como "arte visionario" (Visionary experience in the Golden Age of Spanish Art. Londres, Reaktion Books, 1995). Entre nosotros, los estudios de Emilio Orozco Díaz resultan ejemplares en este campo. No obstante las matizaciones que se hacen a continuación, considero que constituye una vía de análisis muy esclarecedora en el estudio de la transición a una estética naturalista. Un acertado balance historiográfico de la cuestión en HENARES CUÉLLAR, I. y JUSTICIA SEGOVIA, J. J.: "Significación de San Juan de la Cruz en el arte de su tiempo", en AA. VV.: Iconografía y arte carmelitanos. Madrid, Junta de Andalucía-Turner, 1991, págs. $11-15$.

${ }^{3}$ Además de dibujos y pequeñas esculturitas realizadas por el místico carmelita según sus biógrafos, una crónica manuscrita de 1658 citaba "una Virgen de talla esculpida por el Santo" conservada por entonces en el Convento de los Mártires, según noticia de Gómez-Moreno Martínez (cf. SÁNCHEZ CANTÓN, F. J.: “¿Cabe hablar de San Juan de la Cruz y las artes?”, Escorial. Revista de Cultura y Letras, 25, Madrid, 1942, pág. 308 y nota 28).
} 
relacionable con este escultor, invita a reflexionar sobre esta relación, a sondear la posible influencia en ella del gran místico San Juan de la Cruz y a describir conceptual y cronológicamente la transición a una plástica naturalista.

\section{LA HERMANDAD DE JESÚS NAZARENO Y EL CONVENTO DE LOS MÁRTIRES}

Como otras corporaciones penitenciales de la ciudad, la Hermandad de Jesús Nazareno y Santa Elena, bien estudiada por el profesor Szmolka ${ }^{4}$, se funda con el aliento de una comunidad conventual, los carmelitas descalzos de los Mártires (establecidos en Granada en 1573), sobre una realidad devocional anterior, consagrada a la Invención de la Santa Cruz y Santa Elena. La promoción por los conventos de la ciudad resultó decisiva en la consolidación de las hermandades penitenciales granadinas en el último tercio del siglo XVI, sobre todo en las décadas de 1570 y 1580 . Una tras otra, las distintas órdenes acogen hermandades de este tipo: agustinos calzados, carmelitas calzados y reformados o descalzos, franciscanos observantes y terceros, dominicos, mercedarios calzados y mínimos encuentran en estas realidades asociativas una vía de proyección sobre el tejido social ciudadano, una mejora en la economía de los conventos a través de la colecturía de limosnas, así como un cauce a la nueva religiosidad exaltada y triunfalista que materializa la afirmación católica a través de las manifestaciones públicas desarrolladas por este género de corporaciones; incluso se ofrecía con ellas una plataforma de representación social para los distintos estamentos y la generalización de las imágenes devocionales, en el delicado momento posterior a la superación del problema morisco5.

El momento del establecimiento de la reforma masculina del Carmelo resultaba especialmente complejo, tras la reciente sublevación morisca que demostró inútil la política de asimilación desplegada hasta entonces y desembocó en un momento de radicalización político-religiosa. En esta coyuntura y con el apoyo de los marqueses de Mondéjar, capitanes generales de la Alhambra (en cuya jurisdicción quedaba el convento), la fundación de carmelitas descalzos venía a reivindicar el valor simbólico del Cerro de los Mártires, actualizado tras el baño de sangre de la reciente sublevación, especialmente en las Alpujarras.

Alli los descalzos promocionaron una de las devociones características de la orden, la de Jesús Nazareno, reformando o refundando la antigua Hermandad de Santa Elena (llegada a la ermita de los Mártires un poco antes que los carmelitas, hacia 1570) en una asociación devocional de carácter penitencial hacia 1587 o aun antes. Era frecuen-

\footnotetext{
4 SZMOLKA CLARES, J.: "La historia de la Semana Santa granadina desde sus origenes hasta el siglo XVII", en Semana Santa en Granada. Sevilla, Gemisa, 1990, t. I, pág. 35 y ss.; "La devoción a Jesús Nazareno en Granada. La primitiva Hermandad de las Cruces de Santa Helena y Jesús Nazareno”, en ARANDA DONCEL, J. (coord.): Actas del Congreso Internacional “Cristóbal de Santa Catalina y las Cofradias de Jesús Nazareno". Córdoba, Ayuntamiento de Mérida-Hermanas Hospitalarias de Jesús Nazareno, 1991, págs. 443-451; "La religiosidad popular granadina y San Juan de la Cruz", en Congreso "IV Centenario de la muerte de San Juan de la Cruz". Jaén, Centro asociado de la U.N.E.D., 1992, págs. 187-201.

5 Vid. LOPEZ-GUADALUPE MUÑOZ, M. L. y LÓPEZ-GUADALUPE MUÑOZ, J. J.: Historia viva de la Semana Santa de Granada. Arte y devoción. Granada, Universidad, 2002, págs. 97-102.
} 
te la asociación devocional de la Pasión de Cristo y, en concreto, de Jesús Nazareno con Santa Elena, en lógica relación de ideas: "quiso Su Majestad por su misericordia y por los merecimientos de la gloriosa Santa Elena descubrirle el lugar donde estaba [la cruz de Cristo] para que con tal estandarte tengamos siempre en la memoria lo mucho que por nosotros ha padecido"6. Con el tiempo adquirió un sello aristocrático, quizás favorecida por su ubicación extramuros, alejada del entramado urbano y por la pertenencia a la jurisdicción castrense de la Alhambra. Así parece recogerlo, en tono encomiástico, el cronista Henríquez de Jorquera al citar "la devota cofradía de Jesús Nazareno y Sancta Elena, que sale de penitencia el Viernes sancto por la madrugada y la sirven los mejores caballeros de Granada con grande devoción y edificación"7. Su localización creaba no sólo una distancia física, sino también simbólica, que ritualizaba el itinerario procesional de su hermandad, a modo de verdadera Calle de la Amargura.

De hecho, la nueva cofradía inaugura un nuevo paradigma procesional, en el que la violencia física de las disciplinas se troca en mortificación itinerante e imitativa de Cristo al portar como Él una cruz al hombro. La hermandad inspira su sencillez y su piedad cristocéntrica en la reforma del Carmelo, como otras hermandades tomaban el sello de las devociones y carismas propios de cada orden religiosa. Su estrecha vinculación a la orden lo revela la ausencia de hermano mayor, al estar presidida en realidad por el prior conventual, por lo que el máximo cargo de la corporación era el de alférez. Otros datos ofrecen sus reglas, conocidas indirectamente a través de otras que las imitaron ${ }^{8}$, que pueden leerse en el sentido apuntado, como la ausencia de disciplinantes que parece más acorde a la espiritualidad intima de los carmelitas calzados que el modelo vigente de disciplina pública'. Incluso consagra el modelo de Cofradia con imagen procesional, que lentamente se va imponiendo en la segunda mitad del Quinientos ${ }^{10}, y$, aun sospecho, que más rápidamente tras la resolución del

6 SZMOLKA CLARES, J.: “La devoción a Jesús Nazareno en Granada...”, pág. 446. Otro ejemplo es la Hermandad de los Nazarenos de Málaga, conocida como "los Elenos" (cfr. SÁNCHEZ LOPEZ, J. A.: El alma de la madera. Cinco siglos de Iconografía y Escultura procesional en Málaga. Málaga, Hermandad de la Amargura, 1996, págs. 169-171 y "Visión barroca de un ciclo medieval: la leyenda de la Vera Cruz y el entorno iconográfico de la Archicofradía de la Sangre de Antequera”, Via Crucis, 14, Málaga, 1992, pág. 35).

7 HENRIQUEZ DE JORQUERA, F.: Anales de Granada. Granada, Facultad de Letras, 1934 (ed. preparada sobre el manuscrito original por Antonio Marin Ocete; ed. facsimil en Granada, Universidad, 1987), pág. 240.

8 En cofradías de devociones propagadas por órdenes religiosas (caso de la Vera Cruz y los franciscanos) era común la reiteración de las reglas sujetas a un modelo común. Es el caso de ésta y otras cofradias de Jesús Nazareno, auspiciadas por los carmelitas descalzos, como las de Baeza en 1587 o Mancha Real en 1596 (ORTEGA Y SAGRISTA, R.: "La vida religiosa en Mancha Real durante el siglo XVI”, Boletín del Instituto de Estudios Giennenses, 10, Jaén, 1954, pág. 81 y ss.; SZMOLKA CLARES, J.: "La religiosidad...", pág. 196 y ss.).

9 No era asi para la mortificación privada e incluso parece que cierta disciplina semipública era del agrado de San Juan de la Cruz, quizás inspirador de estas reglas. Se trata de los simulacros de martirios de frailes en los que éstos (entre ellos el propio Santo) eran azotados para forzarlos a renegar de su fe, lo que nunca ocurría, con valor ejemplar para los novicios del convento. Así está descrito durante una visita de San Juan al convento de Mancha Real (MORALES PADILLA, M. D. y ROSA OLMEDO, B.: "Fundación y evolución del convento carmelita descalzo de Mancha Real", en Congreso "IV Centenario de la muerte...", pág. 130).

${ }^{10}$ En principio no era frecuente el procesionar imágenes, a no ser de pequeño formato, portadas por una sola persona. 
conflicto morisco. La espiritualidad de esta cofradía resumía los consejos reiterados por San Juan de la Cruz en sus epístolas: silencio, paciencia y mortificación, como vía ascética; el Santo abulense recomendaba en comunicación epistolar: “...jamás, si quiere llegar a poseer a Cristo, le busque sin la Cruz..."11, lo que de forma veraz y aun mimética verificaban los hermanos «nazarenos», portadores de cruces, correlato fáctico de una actitud ética de profundo calado y enorme difusión en la literatura devocional de la época. Su recorrido silencioso también emulaba aquel valor moral del silencio, "soledad sonora", descrito por el santo: "el hablar distrae, y el callar y obrar recoge y da fuerza al espíritu", lo que de paso demuestra bien a las claras el carácter dinámico y militante de la espiritualidad contrarreformista, a la que también pertenece la dinámica de las imágenes procesionales.

Participaba esta hermandad, en fin, del clima general de creciente radicalización de la confesionalidad católica que tiene lugar en época filipina, una radicalización que, aunque con sustento espiritualista, resultaba más efectiva y operativa a un nivel menos racionalista y más emocional, que tenía desde antiguo un perfecto cauce de fervores en las imágenes devocionales. De ahí que, aun no siendo lo pretendido, se observe una profunda ritualización de la religión, con la promoción de grandes manifestaciones religiosas públicas.

\section{SAN JUAN DE LA CRUZ Y EL NAZARENO. MATICES Éticos A UNA IMAGEN}

La formación de San Juan de la Cruz con jesuitas cercanos a la espiritualidad afectivista del recogimiento, aunque considerada peligrosa y perseguida en época de Felipe II como sospechosa de "alumbradismo», predispuso al reformador carmelita a una religiosidad en buena parte basada en la vivencia interior ${ }^{12}$. Esto da que pensar hasta qué punto no resulta contraria a las manifestaciones públicas y ritualistas de los cortejos procesionales, aun en modos embrionarios como los desarrollados en el último cuarto del siglo XVI. Ciertamente, no hay relación evidente, pero si se mira bien no dejan de servir como metáforas visuales del proceso de conversión interior, de vivificación mística del espíritu que propugna la espiritualidad, por ejemplo, de los carmelitas descalzos, aunque no al alcance de todas las mentes y sensibilidades. Quizás el modo de procesionar, sin la estridencia de la violencia física que representa la pública disciplina, sea fruto de esa espiritualidad afectivista. Ello habilita la búsqueda de determinados matices en el modelo de imagen de Cristo con la cruz a cuestas que representa el antiguo Jesús Nazareno de los Mártires, de la mano del escultor alcalaíno Pablo de Rojas, así como en su modo de procesionar, que encuentra una inspiración más o menos directa en la espiritualidad del reformador carmelita. No obsta esto para que esos caracteres insuflen una estética deudora del clima religioso general de su tiempo y que se propaguen rápidamente en la imagineria procesional finisecular.

\footnotetext{
${ }^{11}$ Cfr. LEÓN PADILLA, M. P.: "Fray Juan de Santo Matía: el religioso... Fray Juan de la Cruz: el reformador y místico... Juan de Yepes y Álvarez: el hombre y sus cartas, desde Jaén, a sus amigos...", en Congreso "IV Centenario de la muerte...", págs. 101 y 107.

${ }^{12}$ Una visión de la evolución de la religiosidad de este siglo en AVILÉS FERNÁNDEZ, M.: "El contexto social de la espiritualidad de San Juan de la Cruz", en Congreso "IV Centenario de la muerte...", págs. 15-32; a lo que este trabajo concierne, vid. especialmente pág. 29 y ss.
} 


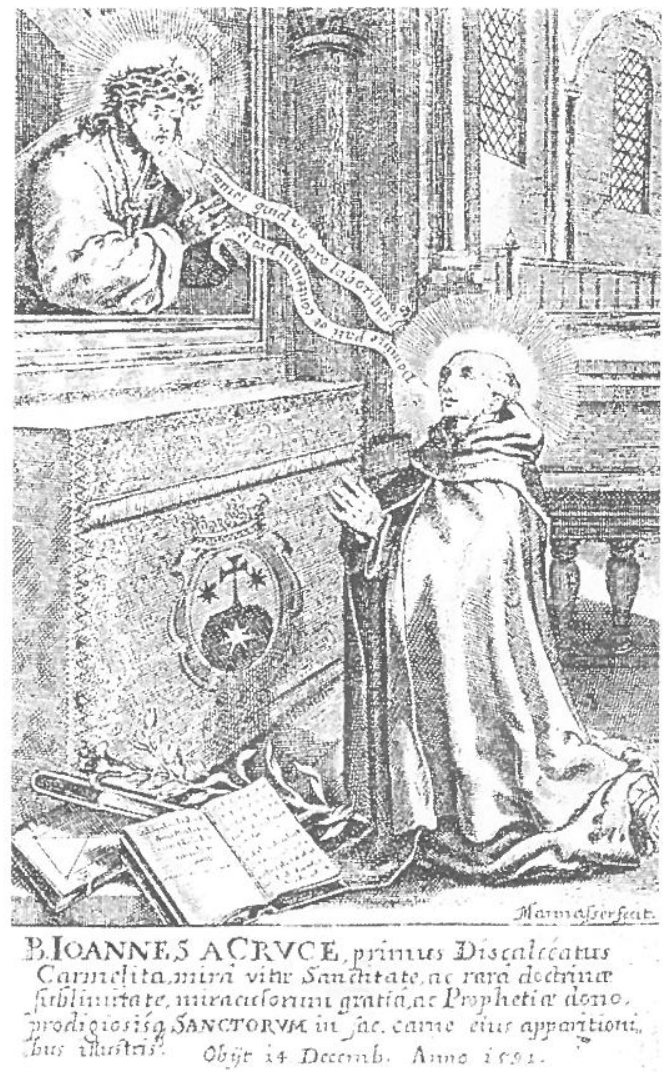

1. Mannafser. Milagro de Segovia, 1675. De la obra Synopsis Admirabilis Vitae B. D. Joannis a Cruce..., por Jerónimo de San José (1675)

En primer lugar, es difícil sustraerse a la tentación de ver en la contemplación de las imágenes en procesión como referencia a su prototipo - con algo de visión sobrenatural, que venian a cumplir una misión catequética y una pulsión afectiva (de catarsis colectiva) - algo de ese ideal de "estar en el mundo, sin ser del mundo" que propugnaba el Santo. Debía ser necesariamente un relato paralelo, un soporte visual de un movimiento interior, más profundo. De hecho, Orozco Díaz ya recalcó la tendencia de los escritores místicos a la visión plástica, incluso superior a la del artista por la fuerza con que la percibía y por el origen sobrenatural de la imagen, no procedente de la imaginación creadora ${ }^{13}$. Probablemente de ahí, y del clima general de la época, nace el reconocimiento del reformador a las imágenes religiosas en su obra Subida al Monte Carmelo: "el uso de las imágenes para dos fines principales ordenó la Iglesia, es a saber: para reverenciar a los santos en ellas, y para mover la voluntad y despertar la devoción por ellas y a ellas. Y cuanto sirven de esto son provechosas: y el uso de ellas es necesario; por eso, las que más al propio y vivo están sacadas, y más mueven la voluntad a devoción se han de escoger, poniendo los ojos en esto más que en el valor de la curiosidad de la hechura de su ornato"14. Junto al reconocimiento, sancionado secularmente por el magisterio de la Iglesia, del valor catequético y devo-

${ }^{13}$ OROZCO DİAZ, E.: "El misticismo de San Juan de la Cruz", Cuadernos de Arte, 3, Granada, 1938, pág. 33.

14 Subida del Monte Carmelo, III, 32. No obstante, también advertía de la naturaleza espiritual del sentimiento religioso pues "a la persona devota de veras en lo invisible principalmente pone su devoción, y pocas imágenes ha menester”, y ponía en guardia ante una sensibilización emocional y epidérmica sin conversión espiritual: "Tenga por cierto el alma que cuanto más asida con propiedad estuviera a la imagen o motivo sensible, menos subirá a Dios su devoción y oración” (Ibidem, III, 34).

${ }_{15}$ MORENO CUADRO, F.: "Jesús Nazareno y el grabado carmelitano", en ARANDA DONCEL, J. (coord.): Actas del Congreso Internacional "Cristóbal de Santa Catalina...", pág. 775 y ss. 
cional de las imágenes, parece percibirse un interés por la representación naturalista en el aserto del reformador carmelita.

De hecho, los grabados del llamado «Milagro de Segovia» (Fig. 1) -acontecimiento que, sin embargo, ocurrió ante una imagen de Cristo crucificado, según el relato del propio Santo- consagran la relación figurativa de San Juan de la Cruz con el tipo iconográfico de Cristo con la cruz a cuestas o Nazareno, al representarlo arrodillado en sacra conversatio ante una imagen (normalmente un lienzo) de esta representación $n^{15}$. Documenta, al menos gráficamente, el lógico uso de las imágenes devocionales por parte del Santo; sin embargo, parece más acorde a la espiritualidad intimista y elevada del reformador abulense el encuentro devocional de oratorio que la manifestación pública de la imagen procesional. Aun admitiendo el valor de la excitación sensorial, el recogimiento y la enfervorización misticas parecen no tener mucho que ver con las prácticas públicas y colectivas, donde lo ritual no necesariamente comportaba la elevación espiritual, al revés era el medio adecuado para una religiosidad popular no por sincera menos epidérmica. Sin embargo, hay que comprender que el complejo panorama de la Granada del momento, apenas década y media después de la sublevación de las Alpujarras y con un importantísimo contingente poblacional converso de religiosidad aún por desarrollar, hacía especialmente valiosas estas manifestaciones públicas, de amplia difusión ${ }^{16}$.

Quizás por ello, si no vehemente, la relación de San Juan de la Cruz con la devoción granadina a Jesús Nazareno y a la hermandad constituida en el convento de los Mártires fue evidente. Bajo su priorazgo se funda la hermandad y como prior presidió sus actos de culto y de gobierno. No debió ser ajeno al potencial catequético de las imágenes, a las enormes posibilidades de adoctrinamiento y a los poderosos atractivos de las manifestaciones públicas de la religiosidad popular. La espiritualidad elevada e intimista de San Juan de la Cruz, más desarrollada en los círculos selectos de sus discípulos o dirigidos espirituales, no obstante, debió advertir la importancia de un compromiso al tiempo individual, en el acto penitencial que cada hermano realizaba, y comunitario, en el conjunto de la cofradía en estación de penitencia, así como su proyección social con fines de conversión a modo de catarsis colectiva. Tanto participantes como asistentes podían percibir sensorialmente aquellas punzantes reflexiones de los libros de devoción sobre la Pasión de Cristo, de carácter moralizante y conmovedor, reforzadas por la contemplación visual, que adquiría así una enorme trascendencia ética.

Al respecto, cabe aducir, siguiendo a los biógrafos de San Juan de la Cruz, que el místico se enternecía ante las imágenes de Cristo en su Pasión por lo que las representaciones figurativas fueron de gran estímulo en su vida, empleando incluso medios teatrales como incentivo de la vida espiritual en el interior de los conventos. Por ello, no es arriesgado pensar que la realización de la imagen de Jesús Nazareno bajo su priorazgo estuviera condicionada por sus propias indicaciones, como la plástica espiritualista, algo intimista, de esta imagen en confrontación con los demás Nazarenos

16 Pero también su control, de lo que se ocuparon sucesivamente los arzobispos Méndez de Salvatierra y Pedro de Castro. 
atribuidos a Rojas parece corroborar. Sabemos por las mismas fuentes que la escultura fue algo próximo al Santo, quien se formó en su juventud en los oficios de entallador y pintor, y labró Cristos de madera en el monasterio del Calvario. Al fin y al cabo, como defiende Orozco, la aspiración de místicos y escultores era una misma ${ }^{17}$.

\section{EL NAZARENO DE LOS MÁRTIRES Y LOS ORÍGENES DE LA ESCULTURA PROCESIONAL ANDALUZA. INNOVACIONES PARA UN PATRÓN FORMAL BARROCO}

En estas coordenadas socio-religiosas, la imagen de Jesús Nazareno del antiguo convento de los Mártires (FIG. 2), actualmente en la parroquia de Huétor Vega (Granada), se revela como un importante punto de inflexión en la valoración y función de la imagen religiosa devocional y en la orientación estética naturalista que inicia el desarrollo de la plástica barroca y el género de la escultura procesional. En este sentido, su autor, el escultor Pablo de Rojas, se convierte en fiel intérprete de las ideas religiosas de su época y en testigo de una evolución social, ideológica y estética que encuentra uno de los principales argumentos de su retórica visual en imágenes como la analizada.

La imago pietatis medieval y aun de la Edad Moderna pretridentina es suplantada por un nuevo tipo de imagen que atesora el valor conceptual de contenidos éticos y teológicos, la provocación sensorial y un concepto plástico susceptible de ser contemplado desde todos los puntos de vista durante su exhibición pública en las prácticas procesionales. Pero a estos valores, más o menos implícitos en la imaginería devocional española al menos desde inicios del Renacimiento, se une una renovación formal que equilibra naturalismo y clasicismo a la búsqueda de la idealización de un icono, como procedente de una visión, que, sin embargo, se debe percibir cercano, como en la sobreexcitación sensorial de las experiencias místicas.

Fruto, sin duda, de su tiempo, en el que Granada añade el carácter distintivo de lo reciente de su recristianización y del aún caliente conflicto morisco, esta imagen y, en general, las esculturas de Pablo de Rojas acaban por conformar lo que va a ser un patrón formal barroco que en sus valores estéticos genéricos, no tanto descendiendo al terreno concreto de los grafismos singulares, perdurará con fuerza durante la mayor parte del periodo de vigencia del estilo. Lógicamente no se trata de un proceso de extensión local, sino de una encrucijada crucial en buena parte del país, fácilmente perceptible en el contexto andaluz, con el mero cotejo de datos y fechas. Estas últimas décadas del Quinientos representan aquí la consagración del modelo de escultura procesional que en algunos maestros y núcleos artísticos se empieza a gestar desde mediados de la centuria, así como la extensión rápida de la devoción al Nazareno, en forma de imágenes y de corporaciones devocionales en torno a ellas. Sobre la tardía implantación de las imágenes procesionales, valga el dato de que la Hermandad de la Vera Cruz de Sevilla, representante de uno de los grandes paradigmas de la peniten-

\footnotetext{
${ }^{17}$ OROZCO DÍAZ, E.: “El misticismo...”, pág. 38. Sobre el conocimiento de San Juan de la Cruz acerca de la práctica artística, Orozco selecciona preciosos testimonios en págs. 43-45.
} 
2. Atribuido a Pablo de Rojas. Jesús Nazareno (de los Mártires), entre 1582 y 1587. Huétor Vega (Granada), Iglesia parroquial.

cia pública, todavia en 1562 procesionaba un Crucificado de pequeño formato en manos de un religioso ${ }^{18}$. En la misma ciudad, todos los Nazarenos procesionales sevillanos son del siglo XVII, aunque existen imágenes exentas de este tipo iconográfico desde el último tercio del siglo XVI. En comarcas más cercanas a Granada y bajo su influencia artística encontramos imágenes en la órbita de Pablo de Rojas en Archidona y Antequera, una imagen manierista de fines del XVI en Lucena y otra de Juan de Mesa el Mozo en 1609 alli mismo, e incluso pueden constatarse tardíos circuitos de influencia artística como los establecidos entre Motril y Málaga, al fundarse la Hermandad de Jesús Nazareno de la ciudad granadina en 1635 y encargar sus imágenes titulares al escultor turolense (afincado en Málaga) Jusepe Micael

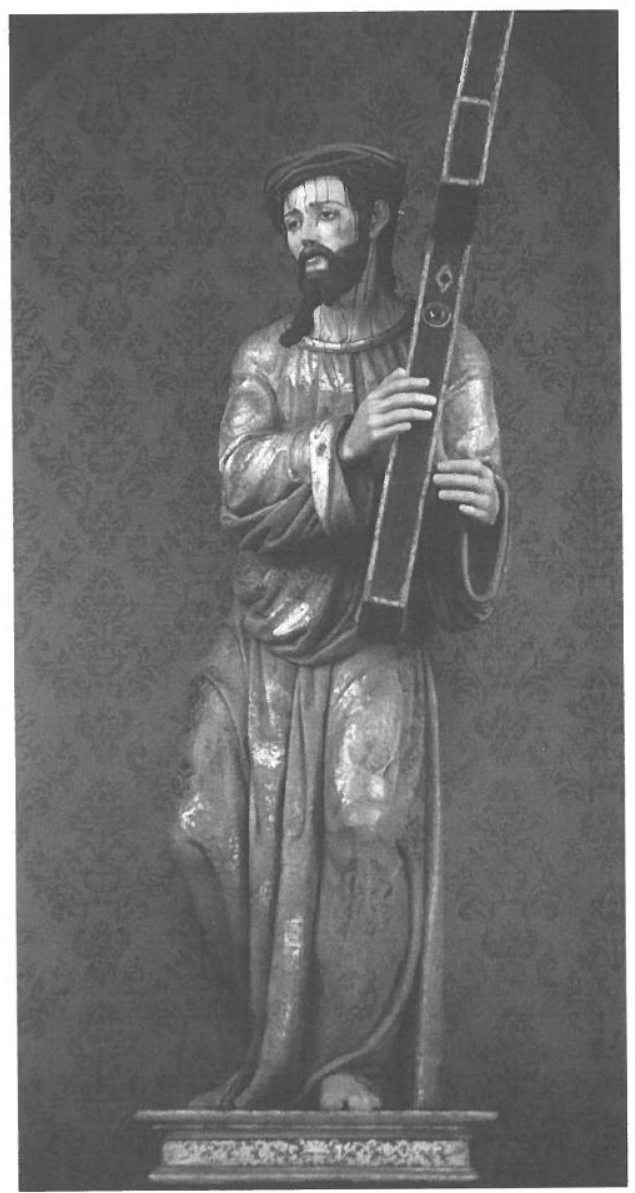
Alfaro a semejanza de las de la Hermandad del Nazareno malacitana ${ }^{19}$. Y en este contexto el Nazareno de los Mártires se convierte en temprana referencia.

Por tanto, asistimos a un momento decisivo de rápida propagación devocional y de renovación plástica en torno al tipo de Cristo con la cruz a cuestas. La iconografía tradicional del Nazareno había configurado una representación marcada por la separación de las piernas y el giro de pies en ángulo recto, como en el acto de recibir

${ }_{18}$ Cf. CARRERO RODRÍGUEZ, J.: Anales de las Cofradías sevillanas. Sevilla, Hermandad de Nuestro Padre Jesús de las Penas, 1984, pág. 637.

${ }^{19}$ LÓPEZ FERNÁNDEZ, D.: "La Cofradía de Jesús Nazareno y Nuestra Señora de la Amargura en Motril (1635-1684)", en ARANDA DONCEL, J. (coord.): Actas del Congreso Internacional "Cristóbal de Santa Catalina...", págs. 467-476. Sobre la importancia de la imagen malagueña como modelo da buena cuenta el contrato de hechura de una imagen de esta iconografía para Marbella: "Un Cristo con su Cruz a cuestas del modelo y hechura que está en Nuestra Señora de la Victoria en la Cofradía de los Elenos” (SÁNCHEZ LÓPEZ, J. A.: El alma de la madera..., pág. 170 y “Visión barroca...”, pág. 35). 


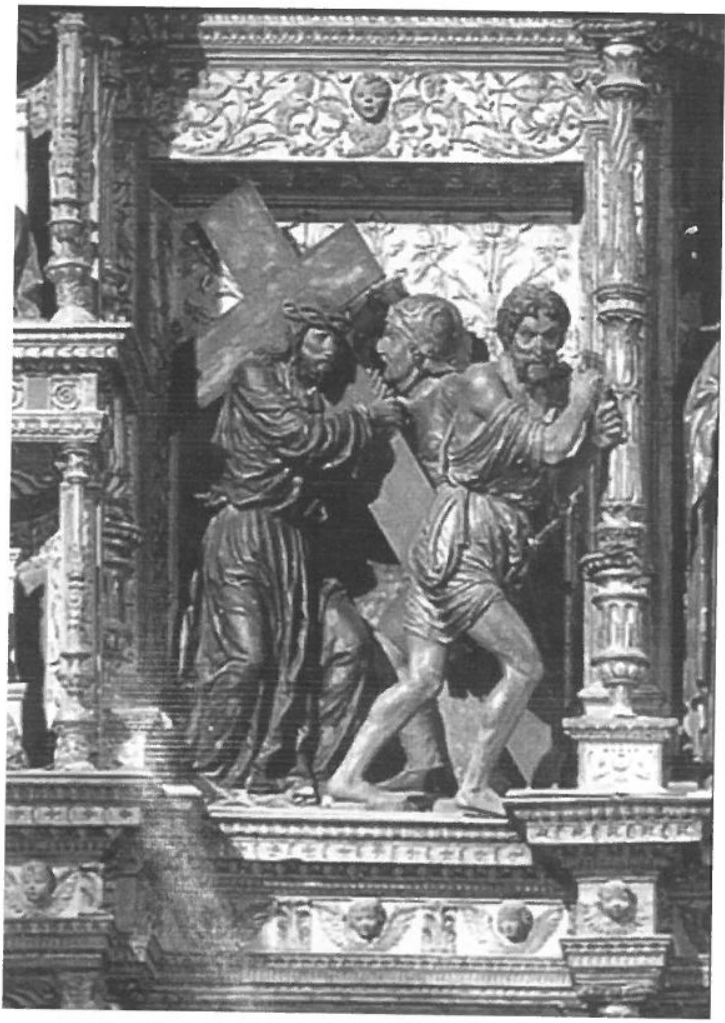

3. Felipe Bigarny. Camino del Calvario, 1522-1526. Granada, Capilla Real (detalle del retablo mayor)

la Cruz, según se presenta en el retablo mayor de la Catedral de Sevilla, por ejemplo, por Jorge y Alejo Fernández Alemán, que, sin embargo, va a adquirir un matiz más dinámico en el coetáneo retablo de la Capilla Real de Granada (1522-1526) en el grupo del Camino del Calvario (FIG. 3) que cupiera atribuir directamente a las gubias del borgoñón Felipe Birgany. Se configura así un modelo bási$\mathrm{co}$, que contiene embrionariamente los valores inherentes a una imagen procesional, en el tema más adecuado para ello por su propia sensación itinerante y que en las últimas décadas del siglo alcanza una importante renovación en la consagración de una composición dinámica de paso más valiente y decidido, de expresión más vehemente. Pablo de Rojas se convierte en figura capital de esta renovación y su modelo se encuentra en el camino que conduce, por ejemplo, a importantes paradigmas de la escultura procesional sevillana como el Jesús de la Pasión de Martínez Montañés, desarrollado aún más en lo dinámico y expresivo por el Jesús del Gran Poder de Juan de Mesa ${ }^{20}$.

El modelo creado por Rojas encuentra un difícil equilibrio entre forma y expresión, en el que funde un bien desarrollado instinto plástico de implicaciones naturalistas y la consolidada herencia clásica del Quinientos. Recoge en él algunos de los matices éticos apuntados, como imagen de gran dulzura y suavidad, que rezuma resignación, inspira compasión e invita a la imitación. Su acento platonizante, manejando generosamente los modelos clásicos, lo quintaesencia Montañés en el Jesús de la Pasión.

\footnotetext{
${ }^{20}$ Sobre el Nazareno en Sevilla vid. CASTILlO UTRILLA, M. J.: "Una iconografía del Nazareno", Archivo Hispalense, 213, Sevilla, 1987, págs. 179-188; GONZÁLEZ GÓMEZ, J. M.: "Iconografía del Nazareno procesional en Sevilla", en ARANDA DONCEL, J. (coord.): Actas del Congreso Internacional “Cristóbal de Santa Catalina...”, págs. 697-714.
} 
En aras de la nueva ecuación entre naturalismo e idealización, e impregnado del trasfondo de los devocionarios místicos, trata con cuidada serenidad la expresión del rostro, el ligero toque de las manos con la cruz, incluso la composición en posición no muy encorvada, como detenida un instante para facilitar la contemplación de un espectador que queda automáticamente trasladado a la Calle de la Amargura e incitado a ir al encuentro del Nazareno como nueva Verónica. Rompe, por tanto, con las violencias expresivas y las rigideces compositivas anteriores para buscar nuevas fórmulas de expresión más naturalistas y consumibles, donde la conjunción de compasión y persuasión refuerza el papel adoctrinador y devocional-afectivo de las imágenes, sobre todo en su pública contemplación en procesión. Cumplen el aserto de San Juan de la Cruz en cuanto a que las imágenes "que más al propio y vivo están sacadas, y más mueven la voluntad a devoción se han de escoger (...)".

A nivel compositivo resulta a un tiempo equilibrado y dinámico. Recoge el tipo tradicional del Quinientos, pero matizado en la soltura del movimiento anatómico, en el equilibrado y no abrupto modelado de paños y en la impresión naturalista del conjunto, sin estridencias expresivas. Se confirmaba así el género de la escultura procesional, que había conocido precedentes granadinos en cuanto a afirmación plástica y carácter dinámico (en el citado retablo mayor de la Capilla Real, por ejemplo) y en impacto sobre la sensibilidad de los espectadores (la realidad lacerante de los Cristos siloescos, aunque no se rastrean versiones del tema en esta línea), pero sin llegar a afianzar las plenas bases del naturalismo ni la completa valoración plástica de la figura exenta, contemplable desde todos los puntos de vista y, por tanto, procesionable.

No es que las imágenes hasta el momento no pudieran ser procesionales. Pero el matiz estético del último cuarto del siglo XVI es diferente y diversas razones lo justifican. Entre ellas se encuentra el hecho de que éstas no son imágenes de altar aprovechadas para procesionar eventualmente, sino concebidas ex profeso para una actividad procesional más o menos regular a iniciativa de las propias hermandades. Por otro lado, es el momento de la afirmación de la fe frente a sus enemigos, tanto protestantes como moriscos (de traumática y reciente "solución»), y la religiosidad popular habla y entiende muy bien el lenguaje de las imágenes. Diríase que cierto respeto a la tradición anicónica musulmana, que hubiera autolimitado la proliferación de las imágenes y, sobre todo, su pública presencia en las calles, queda ahora completamente desbordado y rebasado. Por último, el carácter público, el adoctrinamiento colectivo, la catequización de masas, la pulsión afectiva y devocional recomiendan nuevos rangos expresivos, ensayados en el terreno literario por los libros místicos y de meditación devota y que se transliteran a la objetividad material de la obra de arte a través de propuestas más naturalistas. La dimensión histórica y narrativa de la imagen se diluye un tanto a favor de un acercamiento al fiel, vía sensorial, que pretende actuar sobre sus emociones íntimas y humanas en un plano sicológico, con el peligro de emotivización y falta de base conceptual (léase doctrinal) que ello podría conllevar. No obstante, la diligente y vigilante atención pastoral podia obviar estos riesgos y beneficiarse del enorme potencial comunicativo de las imágenes, capaz de llegar a amplias capas de población.

Descendiendo al terreno concreto de los valores estéticos del nuevo modelo de imagen procesional configurado por Rojas, resulta evidente que el aporte de las alternativas emocionalistas de corte eminentemente expresivo que en Granada repre- 
sentan Siloé y sus seguidores queda definitivamente contenido por una fórmula de naturalismo equilibrado, impregnado de la nobleza de los modelos clásicos de la Antigüedad - constante mediterránea-, de indudable atractivo tanto para la contemplación sosegada e intima, como para la itinerante y pública, expresión heroica de los contenidos doctrinales del Catolicismo y, en concreto, del drama cristiano de la Redención. Las constantes de equilibrio, humanidad y clasicismo son las que hacen de este modelo de imagen religiosa un arquetipo reutilizable durante casi dos siglos, perfectamente compatible y «completable» con los añadidos de cada época, siempre sobre el valor seguro de su enorme atractivo en la piedad popular y con la ventaja de constituir terreno apto para el libre desenvolvimiento de la creatividad individual de cada artista, como las distintas alternativas que la imagineria granadina conoce en las dos centurias siguientes permite corroborar. Por otro lado, la influencia sobre los modos expresivos de Martínez Montañés, ya apuntada, y su consecuente extensión sevillana magnifica la repercusión de este concepto plástico. Posteriormente, en el desarrollo del Barroco granadino la presencia de Cano no hace sino corroborar el idealismo clásico ya anunciado, ejerciendo una influencia de enorme calado.

Pero debe reconocerse también la influencia de ciertas «urgencias» de su tiempo, como va dicho. A tenor de lo prescrito en Trento y, sobre todo, de los decretos arzobispales de 1572 (Constituciones sinodales del Arzobispo Pedro Guerrero) y 1582 (Capitulos de reformación del prelado Juan Méndez de Salvatierra) referentes al «decoro» de las imágenes y contra la «profanidad» de vestirlas, las esculturas de Pablo de Rojas y, en concreto, la serie de tres Nazarenos unánimemente reconocidos por la crítica (el de las Angustias de Granada, el de los Mártires en Huétor Vega y el de Priego) ofrecían la solución plástica adecuada a la corriente religiosa oficial y también en sintonía con la espiritualidad mística, como imagen "pura», es decir, la reflexión doctrinal hecha icono sin otros aditamentos que los de sus propias formas, que buscan en su humanidad la proximidad a la sentimentalidad de los fieles y en su acento idealizante la referencia a su carácter divino. Tanto el decreto sinodal del arzobispo Guerrero ("se guarde y cumpla lo ordenado por el Santo Concilio de Trento, quitando cualquier abuso que en esto haya, especialmente en el ornato de las imágenes, que no se consientan vestidas en iglesias, procesiones, ni otro lugar..." $)^{21}$ como, sobre todo, las medidas de Méndez de Salvatierra resultan taxativas en este punto, al denunciar las "sayas guarnecidas, alçacuellos enriçados, lechuguillas (...) y lo peor es que las suelen afeitar [a las imágenes sagradas] y poner color, cosa indecente aun para las mugeres profanas, para lo qual se piden prestadas ropas, las quales se ven puestas en mujeres particulares, de lo qual hay escandalo"22. En perfecta sintonía, San Juan de la Cruz era partidario de las imágenes de talla completa en lugar de las de vestir, pero poniendo el acento en la impresión viva y naturalista que calara en el espectador ${ }^{23}$.

\footnotetext{
${ }^{21}$ Constituciones sinodales del arzobispo de Granada en el Santo Sínodo que Su Señoría Reverendísima celebró a quatorze días del mes de octubre del año 1572. Granada, por Hugo de Mena, 1573, título XVIII (De reliquiis et veneratione sanctorum et templorum).

${ }_{22}$ Archivo de la Catedral de Granada, libro 20, págs. 916-920; LÓPEZ MUÑOZ, M. L.: Contrarreforma y Cofradias en Granada. Aproximación a la historia de las hermandades y cofradías de la ciudad de Granada durante los siglos XVII y XVIII. Granada, 1992, Tesis doctoral inédita, pág. 725.

${ }^{23}$ OROZCO DÍAZ, E.: "El misticismo...”, pág. 46. Estas medidas forman parte de conjuntos normativos de mayor calado, en los que se atajan ciertas desviaciones de las manifestaciones de la religio
} 
Probablemente esta ecuación entre naturalismo e idealidad, sobre un horizonte clásico aún cercano y cargado de contenidos simbólicos - alusivos a glorias pretéritas que lavaran el traumático episodio del conflicto morisco- resultó alentada desde la jerarquía eclesiástica y propició la renovación plástica que comentamos. La proximidad cronológica de los tres Nazarenos que realizara Rojas para cofradias granadinas (el de las Angustias antes de 1586, el de la Trinidad en ese mismo año y el de los Mártires como muy tarde en 1587 , si no antes) resulta reveladora del interés por ajustarse a los nuevos cánones. En el caso del Nazareno de la Cofradía de la Sagrada Pasión, instituida en el convento de la Trinidad, los términos del contrato dejan bien clara la vigencia de la nueva fórmula por la insistencia en la sujeción al modelo: "...del mismo tamaño y hechura y obra quel paso de la misma significación questá en la iglesia de Nuestra Señora de las Angustias..."24. Estrategia de penetración ideológica, armonía con las corrientes de espiritualidad mística y, por qué no decirlo, delectación estética son los valores que reúne la nueva imagen devocional de carácter procesional, que gana en operatividad y eficacia.

\section{LA SERIE dEL NAzARENO de PABLO dE ROJAS. PROBLEMAS HISTORIOGRÁFICOS Y PRECISIONES ESTILÍSTICAS}

Estos intereses encuentran una formulación eficaz y prototípica en los tipos iconográficos definidos por Pablo de Rojas en las postrimerías del Quinientos, incluyendo éste de Jesús Nazareno o Cristo con la Cruz a cuestas. Son varias las versiones con él relacionadas que nos han llegado y alguna más conocida a través de documentos. El Nazareno de la iglesia de las Angustias de Granada y el de la parroquia de Huétor Vega, proveniente de los Mártires, son las imágenes del grupo de Rojas que mayor cercanía guardan entre sí, lo que sirve de indicio acerca de su cronología, habida cuenta que la primera ya existía en 1586 . El sentido dinámico y compositivo es el mismo. Además de las fuentes grabadas, de prolijo manejo en los talleres de la época, en la propia Granada existian algunas representaciones plásticas que podían ofrecer los rudimentos narrativos para su composición a Rojas. Probablemente no tuvo conocimiento de otra formulación escultórica que la ofrecida por el borgoñón Bigarny en el retablo mayor de la Capilla Real, ya citada, escena en la que a pesar de las distintas manos apreciables en la realización del conjunto - más patente aún tras su reciente restauración-cabe reconocer sin titubeos la huella del maestro, acorde a lo ensayado para el mismo tema en el trasaltar de la catedral de Burgos (1499), sujeta a modelos flamencos, tanto pictóricos como grabados ${ }^{25}$. El acusado dinamismo del grupo

sidad popular como son las procesiones de Semana Santa. Al respecto vid. SZMOLKA CLARES, J.: "Cofradías y control eclesiástico en la Granada barroca", Espacio, Tiempo y Forma, Serie IV, Historia Moderna, 7, Madrid, 1994, págs. 377-396 y LOPEZ-GUADALUPE MUÑOZ, M. L. y LOPEZ-GUADALUPE MUÑNOZ, J. J.: Historia viva de la Semana Santa de Granada..., págs. 119-131.

${ }^{24}$ Archivo de Protocolos Notariales de Granada, leg. 262, fols. 7-8. Citado por GILA MEDINA, L.: "En torno a los Raxis Sardo: Pedro de Raxis y Pablo de Rojas en la segunda mitad del siglo XVI”, Atrio. Revista de Arte, 4, Sevilla, 1992, pág. 42.

${ }_{25}$ RÍO DE LA HOZ, I.: El escultor Felipe Bigarny (h. 1470-1542). Salamanca, Junta de Castilla y León, 2001, pág. 40; LEÓN COLOMA, M. Á.: "El Nazareno de Huétor Vega. La belleza estoica de Pablo de Rojas”, en Huétor Vega. V Centenario de la Parroquia y del Ayuntamiento. Granada, Ayuntamiento de Huétor Vega, 2003, pág. 51. 


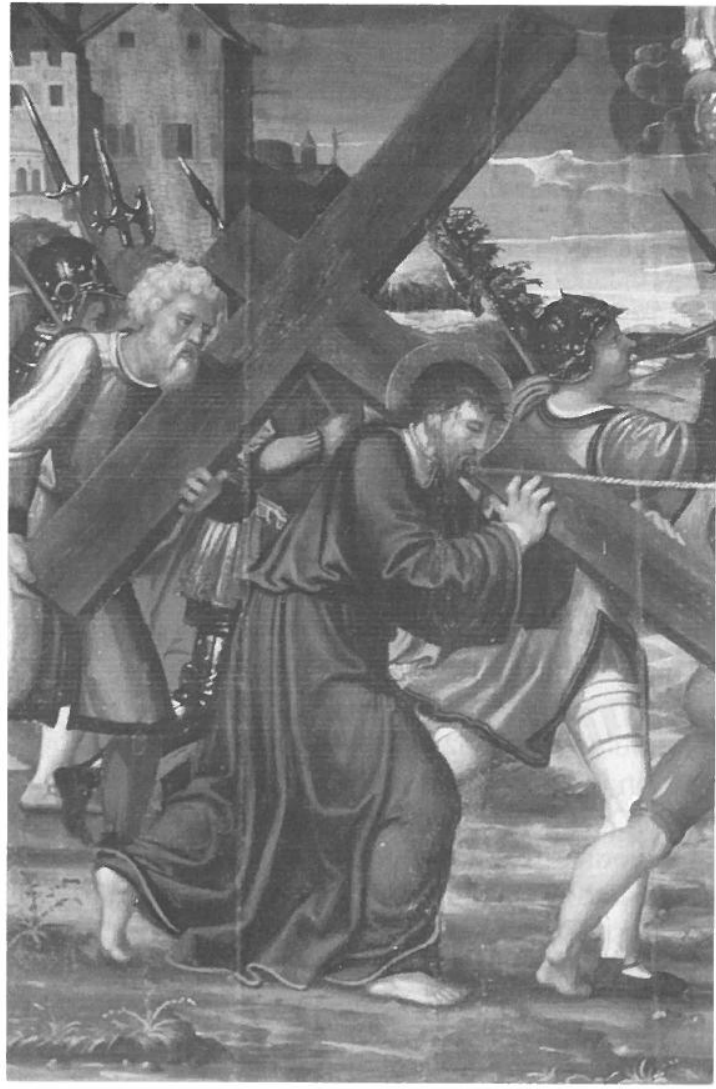

4. Atribuido a Juan Ramírez. Camino del Calvario, principios del siglo XVI. Granada, Iglesia parroquial de San José

de Bigarny, más notable aún en el marco retablístico en el que aparece inserto, al que desborda claramente, y superador en ello del resto de escenas del conjunto, marca la pauta de la representación itinerante de Cristo en el Camino del Calvario, que encuentra en la movilidad un recurso primordial para su configuración como imagen procesional. Rasgos formales tardogóticos como lo pesado de los pliegues de la túnica, su rebosar en la cintura, su ajuste a las rodillas para marcar la flexión de la pierna en el sentido del avance o hasta el detalle anecdótico de las mangas vueltas son reutilizados por Pablo de Rojas para aprovechar lo narrativo, expresivo y dinámico que pueda proporcionar a un nuevo momento en la escultura devocional y a la configuración de un modelo de imagen procesional. Sobre la estampa de Bigarny, el escultor alcalaíno no tuvo más que actualizarla a las demandas culturales y espirituales contemporáneas, y someterla a un ideario estético bien diferente.

En este sentido cabe la consideración de otras fuentes plásticas, aparte de las que por desaparecidas no nos resultan conocidas, ya en el campo pictórico. Coetáneo al examinado, en un retablo atribuido a Juan Ramírez en la parroquia de San José de Granada, la representación del Camino del Calvario ( $F I G .4)$, aunque partiendo de una composición inversa (Cristo abraza el estipes o travesaño largo y no el patibulum o brazo corto como es más habitual) ofrece ciertos detalles narrativos, de inercia medieval, que favorecen el sentido dinámico del modelo que aquilata Rojas a fines del siglo y que son anecdóticos en una imagen de altar pero necesarios en una escultura procesional: el tronco inclinado, acusando la carga que porta; la mayor amplitud del arco de piernas, marcando la zancada con vehemencia; o el pie izquierdo apoyado sólo en la punta, sorprendido en el instante de dar un paso. El campo pictórico es terreno abonado para el descriptivismo de este tipo de escenas. De hecho, el tema del 
Nazareno conoce una importante presencia en la pintura renacentista española, instalándose entre las devociones favoritas no sólo de la nobleza sino aún de la Corona. Le faltaba la validación popular que a través de las imágenes de bulto tiene lugar en las postrimerías del Quinientos y el aliento de órdenes religiosas que, como los carmelitas descalzos o los jesuitas, ligan esta devoción a sus santos más representativos (San Juan de la Cruz y San Ignacio de Loyola, respectivamente). El renovado interés por lo descriptivo en el último tramo del siglo es paralelo al de los escritores místicos, de modo que los artistas plásticos recogen los detalles más vivos e impresionantes de la contemplación pasionista de aquellos.

La prueba de la asimilación de esos elementos narrativos en un tipo de composición nueva nos la ofrece un expediente plástico algo posterior a las imágenes de Rojas y, en cierto modo, deudor de éstas. La pintura de Cristo con la cruz a cuestas de Sánchez Cotán en la Cartuja granadina recoge el espíritu naturalista y la entidad plástica de Pablo de Rojas. Ya Orozco Díaz recalcó la influencia del paso procesional y de los libros de meditación en esta obra de Cotán ${ }^{26}$. La contención expresiva, de resignación diríamos, de la figura de Cristo, se ve arropada por esos detalles narrativos en los que se confía buena parte del impacto vivaz, de impresión fresca y espontánea, en la sensibilidad del espectador y que a estas alturas se han convertido en grafismos consolidados de este tipo iconográfico, como la flexión de la rodilla, el pliegue caído en el borde inferior de la túnica o la inclinación del tronco. Incluso me parece advertir ciertas concomitancias en el rostro, en el saliente pómulo o en el mechón final del bigote. Resulta interesante constatar en este cotejo la repercusión del modelo de Rojas, que se afirma con fuerza de inmediato, y la fluida interacción entre lenguajes plásticos diferentes en un mismo propósito comunicativo.

Sobre las fuentes antes expuestas, la reflexión plástica de Pablo de Rojas opera en la opción metodológica de la imagen procesional, añadiendo los frutos de una composición muy meditada en sus valores expresivos y doctrinales, particularmente en el Nazareno de los Mártires. Y me refiero no sólo a la entidad plástica de una imagen de bulto redondo que, como procesional, puede ser admirada desde todos los ángulos, sino a efectos calculados de relación con el fiel como la sensación impresionante de inestabilidad en la figura, prueba fehaciente del esfuerzo físico, o ese carácter de escena detenida un instante para volver la cara —alta y no humillada como en posteriores versiones barrocas - hacia el fiel, al que orilla en su Vía Dolorosa. En el caso del Nazareno de los Mártires la sugestión más o menos cercana del místico abulense resulta más que probable. El itinerario plástico de este proceso creativo aquilata una figura recia, compacta y serena, de belleza "estoica», como muy bien la ha definido Miguel Ángel León Coloma, que consagra el Nazareno procesional andaluz. El acento platónico idealizante de la imagen de Huétor Vega marca una tendencia de serenidad y mansedumbre en su actitud acorde a la profecía desgarradora de Isaías: "Como cordero llevado al matadero, no abrió la boca" (Is 53,7). Parece trasmutarse con el deseo de desasimiento de San Juan de la Cruz, de entrega perfecta y absoluta de la que sienta magisterio el propio Cristo.

${ }^{26}$ OROZCO DÍAZ, E.: El pintor fray Juan Sánchez Cotán. Granada, Universidad, 1993, pág. 325. 


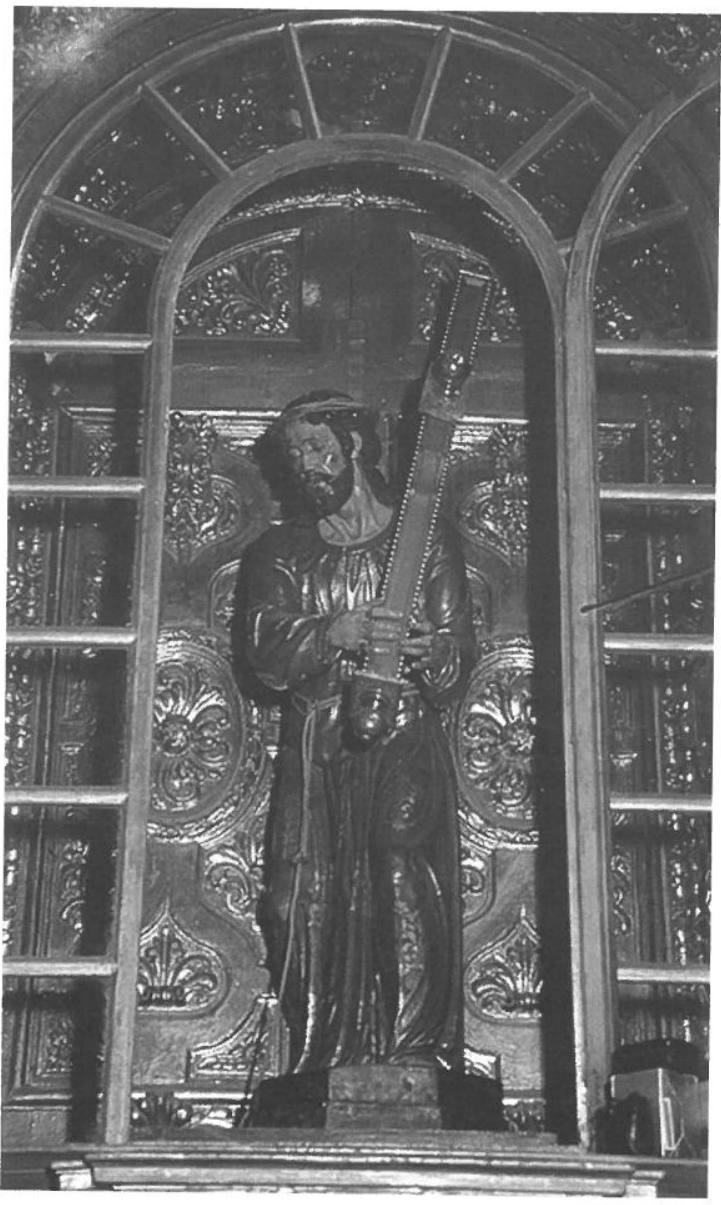

5. Atribuido a Pablo de Rojas. Nuestro Padre Jesús

Nazareno, entre 1582 y 1586. Granada, Basílica de Nuestra Señora de las Angustias

Tanto en el de los Mártires como en el de las Angustias (FIG. 5), el impulso itinerante queda marcado por una ligera inclinación del tronco hacia delante y cierta vehemencia de gesto en la cabeza, con cuello algo alargado, marcando el sendero de la Via Dolorosa. La economía de medios narrativos, esto es, la presentación aislada de la imagen sin el contexto que las pinturas o relieves de retablos le proporcionaban, determina la radicalización expresiva y el ritmo compositivo de la imagen, a los que confía todo su valor comunicativo.

Por otro lado, la cercanía en la técnica, modelado y estética facial es muy acusada en las dos imágenes. Un modelado cuidadoso pero resuelto a grandes planos, marcado por líneas y ángulos que elevan el sentido volumétrico del cuerpo comparten ambos Nazarenos. Los pliegues ligeramente curvados que rozan el suelo en el arco de las piernas subrayan la sensación itinerante que proporciona el pie derecho a punto de levantarse y la pierna correspondiente suelta (FIG. 6). El ángulo descrito por la rodilla izquierda es similar, acusando el peso de la cruz y perfectamente revelado por el modelado de la túnica, especialmente acoplado a la anatomía de la figura en el muslo y la rótula. De igual modo, los pliegues que cuelgan en la cintura por efecto del cordón que ceñiría la túnica, la vuelta de las magnas terciada y dorada, o hasta la distribución de los motivos estofados por la túnica es absolutamente coincidente. Evidentemente, Pablo de Rojas alcanzó una fórmula de enorme éxito tanto doctrinal como devocional en el prototipo de Cristo con la Cruz a cuestas que le llevaría a repetir casi exactamente el mismo modelo al menos en tres ocasiones: en el de las Angustias, otro para el convento de la Santísima Trinidad y éste del convento de los Mártires. 
6. Atribuido a Pablo de Rojas. Jesús Nazareno (de los Mártires). Detalle

El tratamiento de manos no es cotejable al ser postizas las del $\mathrm{Na}$ zareno de los Mártires ${ }^{27}$ y algo torpes y deterioradas - si no es que también añadidas- en el de las Angustias. Divergen ligeramente en el rostro (FIG. 7 y 8). Sobre el patrón básico de Rojas, más achatado que sus precedentes manieristas y de marcada estructura ósea, el $\mathrm{Na}$ zareno de los Mártires revela una impronta naturalista más vehemente, de búsqueda de una cercanía e inmediatez que subraya el carácter afectivo de la imagen en la contemplación del espectador. Recuerda muy bien lo escrito por el propio San Juan de la Cruz sobre las imágenes

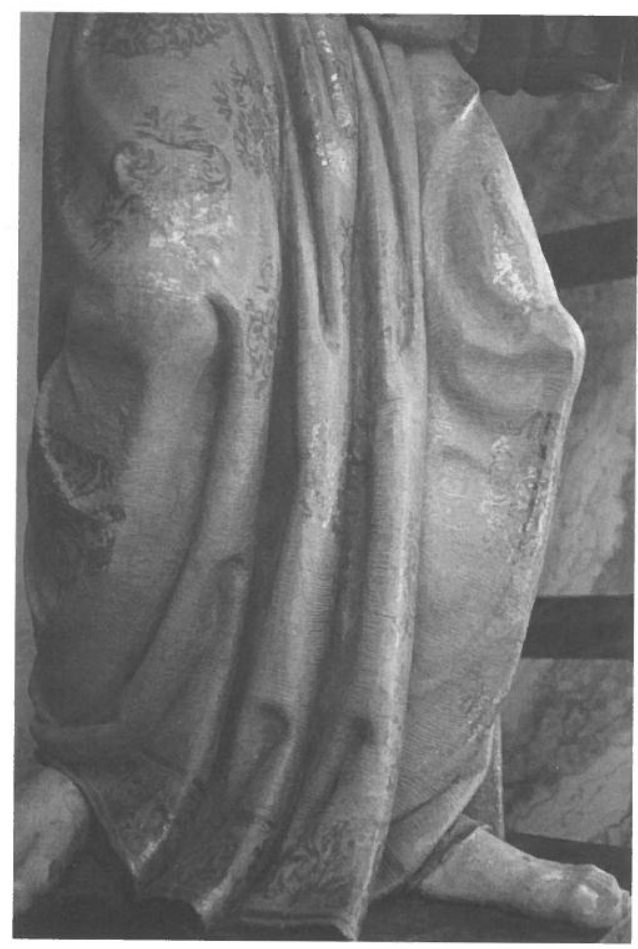
"que más al propio y al vivo están sacadas". Incluso la mirada más alta revela una dimensión comunicativa diferente, en la que se está aquilatando la categorización formal y expresiva de la imagen procesional con nuevos argumentos que añadir al tipo de imagen sólo devocional o de contemplación estática e interior. El valor comunicativo doctrinal que impone la representación aislada, carente de contexto, viene determinado por el pensamiento contrarreformista y el valor concedido a la imitatio Christi, "el valor y mérito de las obras y la imitación de Cristo contra la negación de estos valores tradicionales por el pensamiento protestante. Se fuerza así la argumentación teológica, dando un nuevo y distinto sentido a temas antiguos"28.

\footnotetext{
${ }^{27}$ Así se concluye en el informe de la intervención llevada a cabo en la imagen en 1999 por el equipo dirigido por Bárbara Hasbach. Datos interesantes proporcionados por el proceso, además de éste, han sido precisar el material (pino salgareño), la espesa imprimación de cola animal que crea problemas de adherencia en las carnaciones como en otras obras relacionadas con Pablo de Rojas (el Cristo a la Columna bajo la advocación de la Paciencia en San Matías de Granada o algunas imágenes del retablo mayor de Albolote), añadidos de sangre a punta de pincel y repolicromado dieciochesco de la túnica o el retallado del pelo para colocar una peluca de cabello natural. Agradezco al párroco de Huétor Vega, don Antonio Martín, su amabilidad y facilidades dadas para la consulta de este informe y el estudio de la imagen.

${ }^{28}$ MARTÍNEZ MEDINA, F. J.: Cultura religiosa en la Granada renacentista y barroca. Estudio iconológico. Granada, Universidad-Facultad de Teología, 1989, pág. 300.
} 


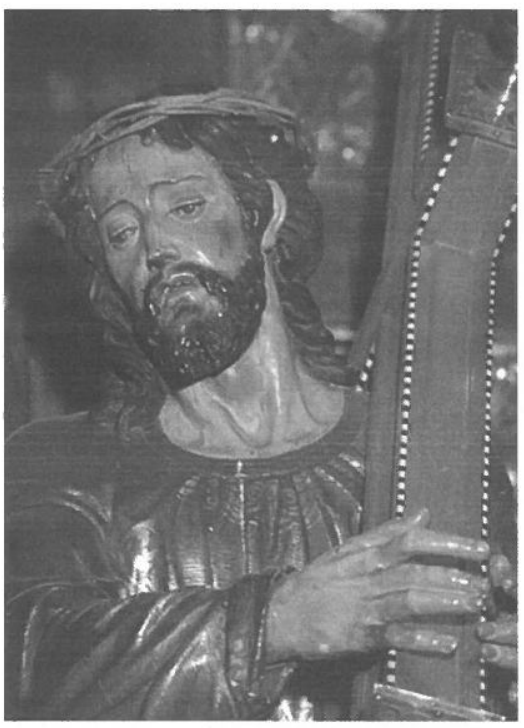

7. Atribuido a Pablo de Rojas. Nuestro Padre Jesús Nazareno (de las Angustias). Detalle

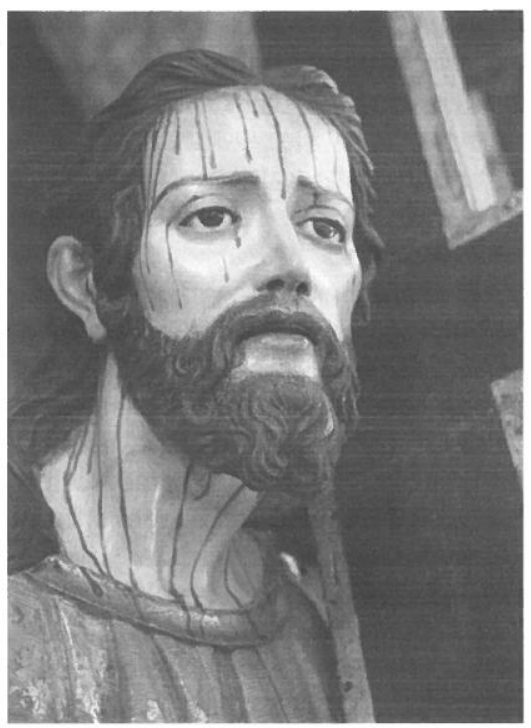

8. Atribuido a Pablo de Rojas. Jesús Nazareno (de los Mártires). Detalle

Las principales diferencias compositivas entre ambas imágenes estriban en la mayor estabilidad y aplomo del Nazareno de las Angustias y una inclinación algo superior de la cabeza en esta misma imagen, con lo que se rectifica el casi vacilante balanceo del tronco del Nazareno de los Mártires. Diríase que se ha querido elegir un momento diferente y concreto, una parada quizás, en la que los espectadores sustituyen a las Santas Mujeres. Aunque las intervenciones en la imagen en el siglo XVIII - parece clara modificación el recorte de la caída de la manga que facilitaría vestirla con túnica de tela ${ }^{29}$ - y de José Gabriel Martín Simón en la década de 1930 alteraron la integridad original de la obra, no pudieron modificar la traza general de la figura. Se sacrifica algo del sentido dinámico de la misma en aras de la comunicación con el devoto, quizás en un análisis de resultados obtenidos y consecuente modificación para mejorarlos, volviéndose algo más dolorida y patética.

Una tercera imagen vinculable al grupo es la de Nuestro Padre Jesús Nazareno de Priego de Córdoba ${ }^{30}$. Justificadamente Orozco la consideró la más antigua de esta

\footnotetext{
29 En fecha incierta se transformó en imagen de vestir. En 1762, por ejemplo, estrenó túnica "de tisú de oro, terciopelo y felpillas, color de púrpura", además de corona de espinas y andas de plata (Archivo de la Hermandad de las Angustias, Libro de Cabildos 1760-1769, 26 de marzo de 1762, fol. 42; por extenso en LOPEZ-GUADALUPE MUÑOZ, M. L. y LOPEZ-GUADALUPE MUÑOZ, J. J.: Nuestra Señora de las Angustias y su Hermandad en la época moderna. Granada, Comares, 1996, pág. 69).

${ }^{3 n}$ Algo menor que la de Huétor Vega, mide $162 \mathrm{~cm}$. por 182 de la granadina.
} 
9. Atribuido a Pablo de Rojas. Nuestro Padre Jesús Nazareno, hacia 1592. Priego de Córdoba, Iglesia de San Francisco. Foto cedida por la Pontificia y Real Cofradía y Hermandad de Nuestro Padre Jesús Nazareno

serie, sin duda por el carácter arcaico de su túnica, de fuerte plasticismo, un tanto artificioso, e incluso por la forzada posición de los pies, con el derecho muy atrasado y completamente perpendicular (o más bien en ángulo obtuso) con respecto al izquierdo (FIG. 9). No obstante, esta composición es un modelo consagrado del arcaísmo griego utilizado para favorecer la pluralidad de puntos de vista de la figura, muy adecuado a su carácter procesional. Es muy probable que el gesto verdaderamente perceptible para el espectador de la imagen en

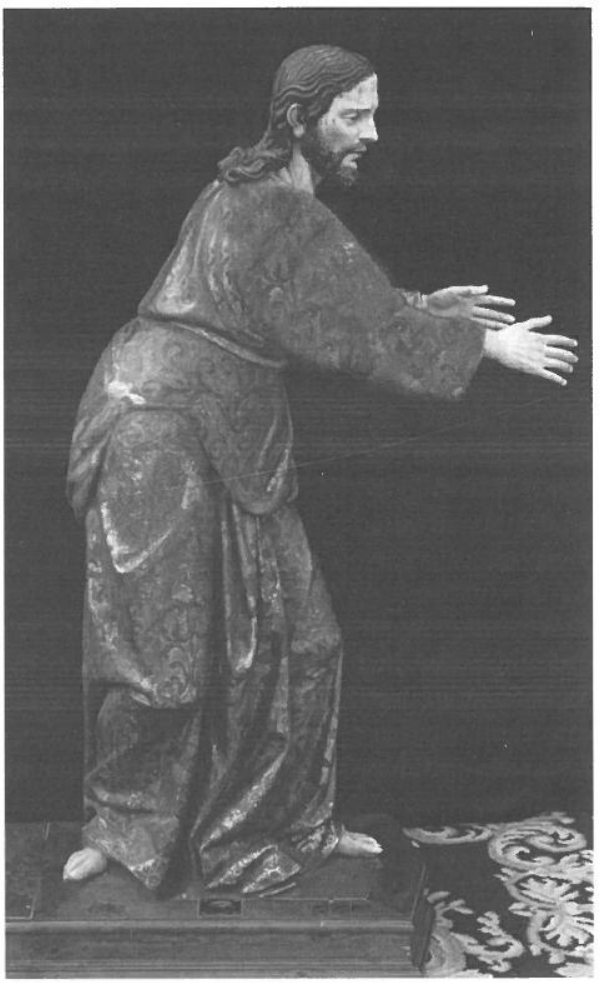
procesión fuera el de la amplia zancada y el esfuerzo en cargar el madero más que la forzada composición de los pies, mucho más al ser vestida, lo que con toda probabilidad ocurriera durante la segunda mitad del siglo XVII o a principios del XVIII ${ }^{31}$. De hecho, esta composición tiene el mismo sentido que el dinámico contraste de planos de los Crucificados de Pablo de Rojas, que sujetan a un orden rítmico la expresividad en movimiento de la figura. A eso puede obedecer el acusado contraste en contragiro entre la posición de las piernas, especialmente la derecha, y el torso. No obstante, la adulteración de la integridad de la talla original para introducir mecanismos de bendición en el hombro y antebrazo derechos no permite leer con seguridad el concepto compositivo con que nació.

Por lo demás, la figura repite los modismos de las imágenes anteriores, sólo que intensificando el volumen y pesadez de los pliegues de la túnica, especialmente en la zona de la cintura, donde el cordón que la estrecha crea amplios pliegues caídos. Resulta probable explicarlo desde la experiencia visual de estampas grabadas

${ }^{31}$ En el primer inventario de su Cofradía, datado en 1602, ya se cita un "sayo", quizás una túnica, mientras que en el siguiente, de 1679 , ya se refieren varias túnicas con este nombre y una cabellera. Cf. REQUEREY BALLESTEROS, R. (coord.): Inventarios históricos y actuales de la Pontificia y Real Cofradia y Hermandad de Nuestro Padre Jesús Nazareno, María Santísima de los Dolores y San Juan Evangelista. Priego de Córdoba, Hermandad de Nuestro Padre Jesús Nazareno, 1999, págs. 70-72. 


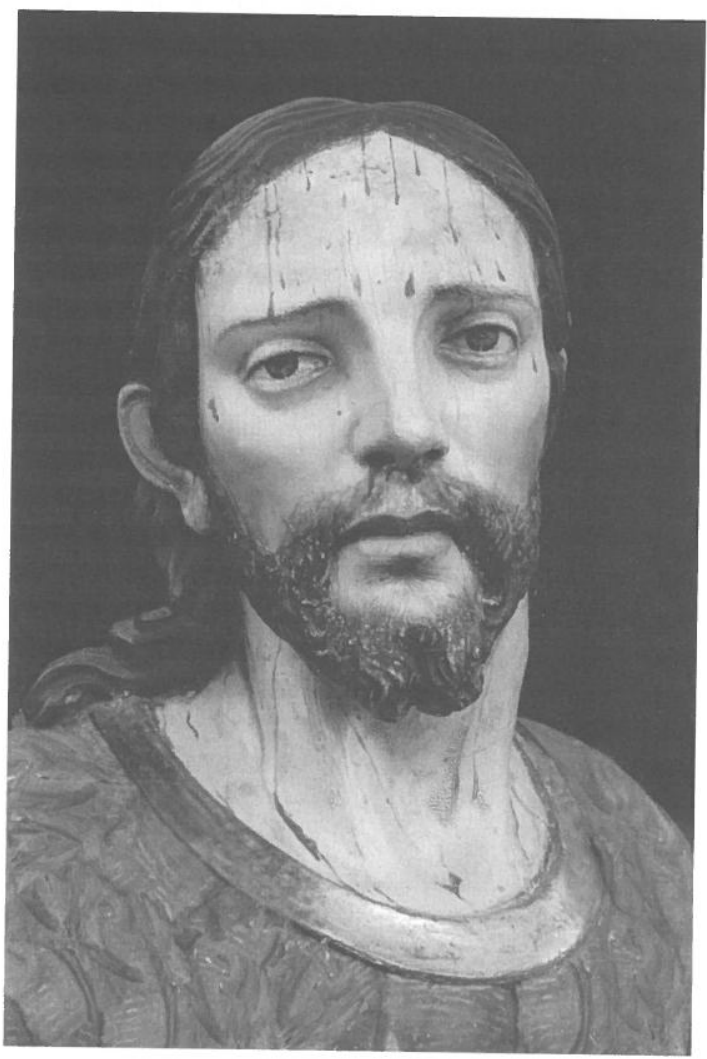

9. Atribuido a Pablo de Rojas. Nuestro Padre Jesús Nazareno (de Priego). Detalle

e incluso de hitos devocionales más antiguos (de Granada o de la propia ciudad de Priego) que condicionaran el encargo y matizaran su materialización. Sin embargo, el rostro (FIG. 10) suscribe plenamente la línea de naturalismo creciente anunciada en las anteriores y sobre la que progresa el $\mathrm{Na}$ zareno prieguense. El rostro achatado, la firmeza de volúmenes en torno a las mejillas, la prominencia de los extremos del bigote, el cabello peinado por encima de la oreja (quizás retallado a la hora de incorporar una peluca de melena natural $^{32}$, la impronta naturalista, en fin, de su mirada y su rictus doloroso sancionan, sobre la base de un modelado de indiscutible calidad y una policromía excelente, la citada progresión naturalista de esta imagen, paralela a la de esculturas coetáneas también atribuidas a Rojas como el Cristo de la Esperanza (1592) de la Sacristía de Beneficiados de la Catedral de Granada.

La imagen del Nazareno del Convento de la Trinidad no ha podido ser identificada, si es que se conserva, lo que es más de lamentar por ser la única fehacientemente documentada y fechada. Sí que se rastrea, sin embargo, el impacto devocional de esta imagen, a través del testimonio del Padre Lachica: "aquel hermoso Simulacro de Jesús Nazareno, de quien se dice que pidiendo a Dios la V. Sor Beatriz de Jesús, Religiosa del Ángel, le revelase qué Imagen era más conforme a su Sagrada Pasión, le respondió el Señor que la de Jesús Nazareno que se venera en la Iglesia de los Trinitarios Calzados de esta Ciudad era semejante a la del mismo Señor en la aflicción de la Calle de la Amargura, quando caminaba a el Calvario a dar por nosotros la Vida" ${ }^{3}$.

\footnotetext{
${ }^{32}$ La única intervención antigua documentada es de 1803 en que la imagen fue ahuecada. Ibidem, pág. 213. En 1981 se renovó el pie derecho en madera de ciprés, además de completar dedos y realizar retoques de policromía en la túnica.

${ }^{33}$ LACHICA BENAVIDES, Fr. A.: Gazetillla curiosa o semanero granadino, noticioso y útil para el bien común, papel X, Granada, 11 de junio de 1764, pl. 2 (el subrayado es del original). Esta
} 
Su porte llamó la atención al Conde de Maule, quien la juzgó como de Becerra, como todas las imágenes de esa etapa que contempló ${ }^{34}$. La imagen siguió procesionando al menos hasta fines del siglo XVIII, como contempla una relación de las Cofradias y pasos que procesionaron en la Semana Santa de $1791^{35}$, y como las del resto de la serie, fue vestida con el tiempo, según anota el inventario de la Desamortización ${ }^{36}$.

Grueso problema en el estudio de este grupo de imágenes es el de la cronología de las mismas, sobre lo que algo hemos apuntado más arriba. La única data cierta es el contrato del Nazareno de la Trinidad en 1586 y que para entonces ya estaba hecho, imagino que recientemente, el de las Angustias. A la luz de los argumentos expuestos, entiendo que el Nazareno de los Mártires fue una versión singularizada - en cierto modo emancipada - de la serie, quizás la primera, entre 1582 y 1587 , y bajo sugestión del prior del convento, San Juan de la Cruz. Una especial impronta espiritual e intimista se observa en esta imagen a diferencia de las continuadoras en la serie. Por esta época (1582), se realizaba el Crucificado de la Cofradía de las Angustias, también atribuido a Rojas ${ }^{37}$, cuyo éxito debió representar un nuevo encargo, la imagen de Jesús Nazareno, al calor también de la novedad que representara aquél del convento de los carmelitas descalzos, por lo que el Nazareno de las Angustias pudo realizarse hacia 1584-1586 y, a su imagen, el citado de la Trinidad, contratado en 1586. El de Priego llegó a esta ciudad en $1592^{38}$, por lo que debe ser de fecha

revelación es especialmente ponderada por el autor de las Gazetillas como religioso precisamente del Convento de la Santísima Trinidad. Por otro lado, el "prodigio" también se explica, como aclara el mismo Lachica poco después, porque la citada religiosa del convento del Ángel Custodio era dirigida espiritual del Provincial de los Trinitarios, fray Pedro Bravo. A pesar de ello, queda claro el interés devocional de la imagen y, sobre todo, el afán naturalista percibido en ella, hasta el punto de ser a los ojos de la religiosa visionaria un trasunto fiel de Cristo en la Calle de la Amargura.

${ }^{34}$ CRUZ Y BAHAMONDE, N. (Conde de Maule): Viaje de España, Francia e Italia. Cádiz, Imprenta Manuel Bosch, 1812, t. XII, pág. 265.

${ }_{35}$ Archivo de la Real Chancillería de Granada, leg. 322-4446-2, analizada en LÓPEZ-GUADALUPE MUÑOZ, M. L. y LÓPEZ-GUADALUPE MUÑNOZ, J. J.: Historia viva de la Semana Santa de Gra$n a d a \ldots$, págs. 226-228. Llama poderosamente la atención el hecho de que de cinco cofradías que procesionaron en ese año, cuatro sacaron a la calle imágenes de Cristo cargando con la cruz: la Hermandad de Jesús Nazareno del Convento de la Trinidad (continuadora de la que encargara la imagen a Rojas en 1586), la homónima del Convento de la Merced, la Cofradía de Nuestra Señora de las Angustias y la de Jesús de las Tres Caídas del Convento de San Francisco Casa Grande. Dato sintomático de esta enorme popularización devocional del Nazareno lo representa la Cofradía de las Angustias. Durante la mayor parte del siglo XVIII esta corporación sólo procesionó las imágenes de Jesús Nazareno y de la Virgen titular, dejando de hacerlo el Crucificado (hoy en la sacristía de su basílica) e incluso las medallas de la época (conservadas en el Museo del Pueblo Español de Madrid) presentan a la actual Patrona de Granada en el anverso y al Nazareno en el reverso, esta última imagen en versión libre distante del original, signo inequívoco del protagonismo alcanzado (cit. por ALARCÓN ROMÁN, C.: "La iconografía religiosa en el siglo XVIII", Revista de Dialectología y Tradiciones Populares, XLV, Madrid, 1990, págs. 267-268).

${ }^{36}$ Archivo Histórico Provincial de Granada, leg. 201-5055-3, inventario fechado el 30 de agosto de 1835. Cita en la tercera capilla de la izquierda del templo de los trinitarios "un altar desnudo, con las Ymágenes de talla de Jesús Nazareno y de $\mathrm{N}^{\text {a }}$. Sa de los Dolores, vestidos”.

${ }^{37}$ LOPEZ-GUADALUPE MUÑOZ, M. L. y LÓPEZ-GUADALUPE MUÑOZ, J. J.: Nuestra Señora de las Angustias..., pág. 63.

${ }^{38}$ Ya constaba cuando se constituye su Hermandad el 4 de abril de 1593, junto a las imágenes de la Virgen de los Dolores y San Juan, también tradicionalmente relacionadas con Rojas, al igual que el Cristo chico, excelente Crucificado de $80 \mathrm{~cm}$ de altura, que se conserva en la sacristia de la Hermandad. 


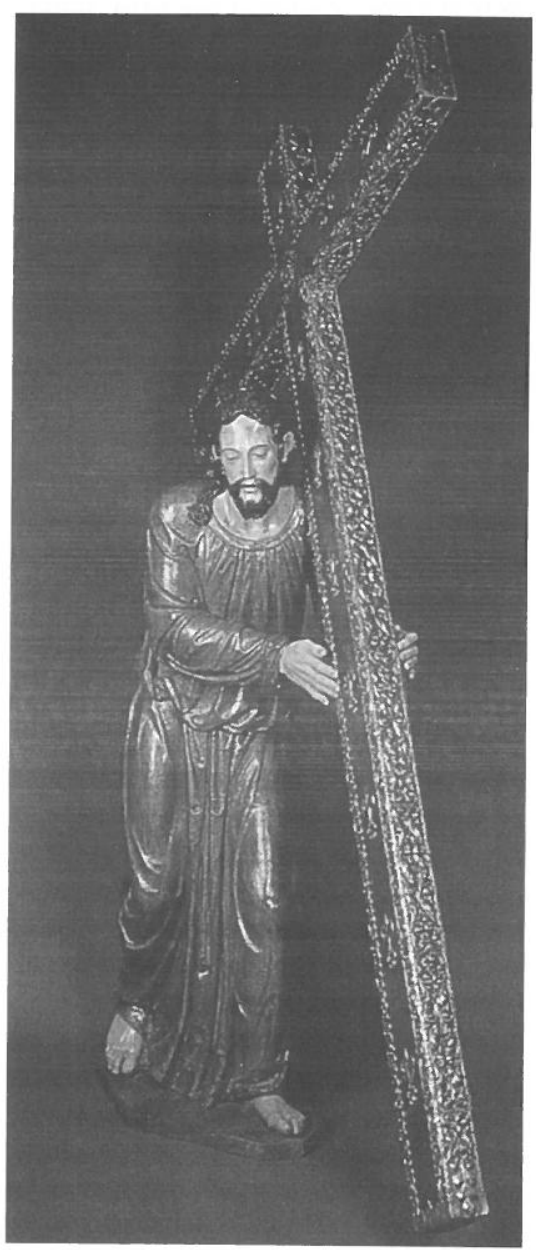

11. Atribuido a Diego de Vega. Jesús Nazareno de la Sangre, hacia 1580 Antequera (Málaga), Iglesia de San Zoilo

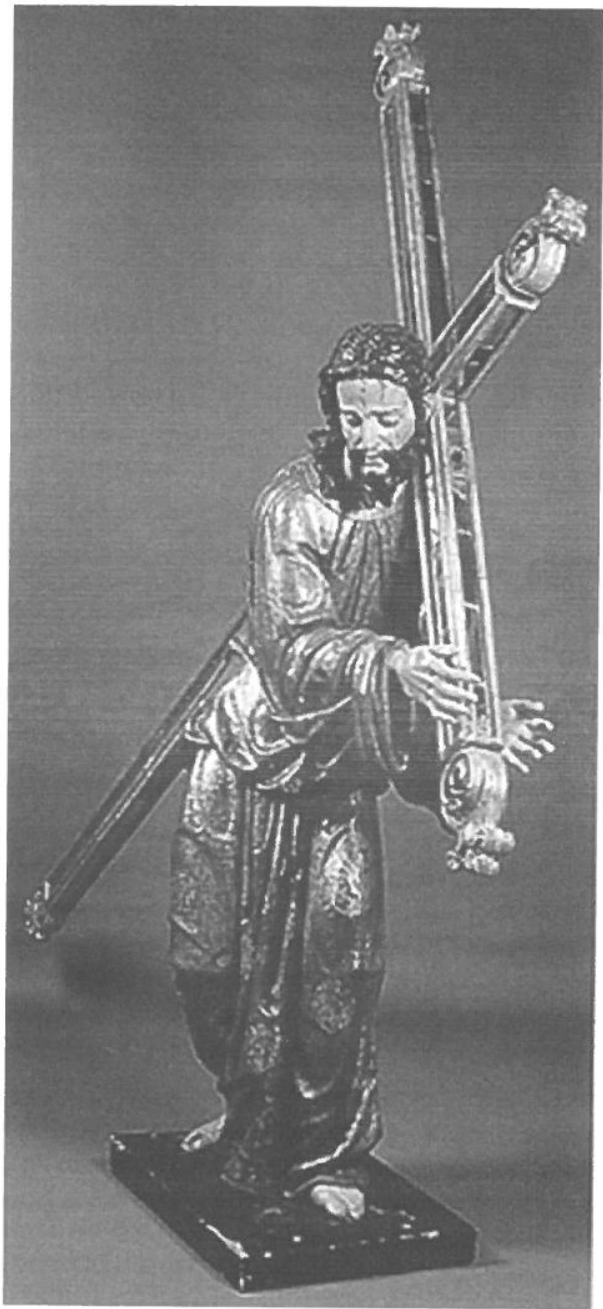

12. Atribuido a Pablo de Rojas. Jesús Nazareno, entre 1580 y 1590. Archidona (Málaga), Ermita del Nazareno

próxima a ese año y, por tanto, el último de la serie. En los dos últimos, el de las Angustias y el de Priego, se observa una revisión «barroca» del prototipo con mínimas diferencias compositivas y expresivas, fruto del estudio pautado del potencial estético y comunicativo de la imagen procesional, según la experiencia acumulada. Lo que se documenta a todas luces es la proliferación de imágenes de esta iconografía, alentada por la descalcez carmelita y quizás un sentimiento de emulación entre estas corporaciones devocionales. En este sentido, cabe recordar que las Cofradías de la Cruces 
de Santa Elena (de los Mártires) y de la Sagrada Pasión (del convento de la Trinidad) tuvieron desafortunados encuentros - más bien desencuentros- en la confluencia entre el Zacatín y la plaza Bib-Rambla en la mañana del Viernes Santo ${ }^{39}$, por lo que parece fácil que el modelo para una Cofradia no fuera el de la rival, sino el de otras, criterios estéticos aparte.

Peliaguda resulta la cuestión de la vinculación a esta serie del Nazareno de la Sangre de San Zoilo de Antequera y de la imagen de Jesús Nazareno de la Ermita del Nazareno de Archidona. Su tradicional vinculación a Pablo de Rojas se ha visto contestada recientemente por una nueva atribución en la figura todavía poco conocida del escultor Diego de Vega, activo en la ciudad de Antequera entre 1577 y 1582, si bien no ha aparecido documentación concluyente al respecto.

Ciertamente, el Nazareno de la Sangre (FIG. 11) antequerano difiere con claridad en el tono general de la imagen con respecto a las obras barajadas de Pablo de Rojas. Resulta mucho más simple de modelado y menos intenso de expresión, aspectos en los que nada influye el hecho de portar la cruz en sentido inverso al habitual. Diferente es el Nazareno archidonense (FIG. 12), de mucha mayor calidad técnica, de labra resuelta y profunda en el trabajo de las telas, de composición muy cercana al Nazareno de los Mártires granadino, incluso en el forzado contraposto que contorsiona el tronco hacia la izquierda para acusar el peso de la cruz, y con la cabeza inclinada al modo del Nazareno de las Angustias, con un rostro de modelado anguloso y expresivo. Pienso que, a falta de datos documentales, se puede seguir sosteniendo la atribución a Pablo de Rojas pues las coincidencias estilísticas son palmarias, a modo de revisión más naturalista del modelo ya utilizado. Sí que resulta de mano diferente el comentado de Antequera. La atribución a Diego de Vega parece lógica, aunque falta un análisis profundo de las obras documentadas de este autor que proporcione el bagaje crítico necesario para razonar con mejor fundamento esta imagen. Lo que si llama la atención es la cronología barajada para la misma, hacia $1580^{40}$, muy temprana con respecto a los otros Nazarenos atribuidos a Pablo de Rojas, claramente posteriores a esta fecha.

\footnotetext{
${ }^{39}$ LÓPEZ-GUADALUPE MUÑOZ, M. L. y LÓPEZ-GUADALUPE MUÑOZ, J. J.: Historia viva de la Semana Santa de Granada..., pág. 98.

${ }^{40}$ ROMERO TORRES, J. L.: “Nazarenos. Diego de Vega (atribuidos)”, en El esplendor de la memoria. El arte de la Iglesia de Málaga. Málaga, Junta de Andalucía-Obispado de Málaga, 1998, págs. 143-145. Sobre Diego de Vega se tienen documentadas obras entre 1577 y 1582 , época en la que casi carecemos de datos de Pablo de Rojas que, sin embargo, debía ser ya un artista formado por la edad que alcanzaba (en torno a la treintena). Vega contrata imágenes, andas y retablos, no sólo en Antequera, sino también en Archidona y en La Roda. Sobre esta iconografía se le documenta un Nazareno en 1581 para la Cofradia del Dulce Nombre de Jesús de Antequera, con cuerpo de telas encoladas, hoy en Santo Domingo de esa ciudad (ESCALANTE JIMÉNEZ, J.: "El círculo escultórico antequerano del siglo XVI", Revista de Estudios Antequeranos, 2, Antequera, 1993, pág. 343 y "Escultores y pintores del círculo antequerano del siglo XVI. Aportaciones documentales”. Boletín de Arte, 20, Málaga, 1999, págs. 115-117), cuyo rostro presenta concomitancias, pero también diferencias, con el Nazareno de la Sangre. Esta cronología obliga como mínimo a reconsiderar la de Pablo de Rojas y las líneas de relación estilística entre ambos, quizás fruto de una fuente común y no dependiente uno de otro.
} 


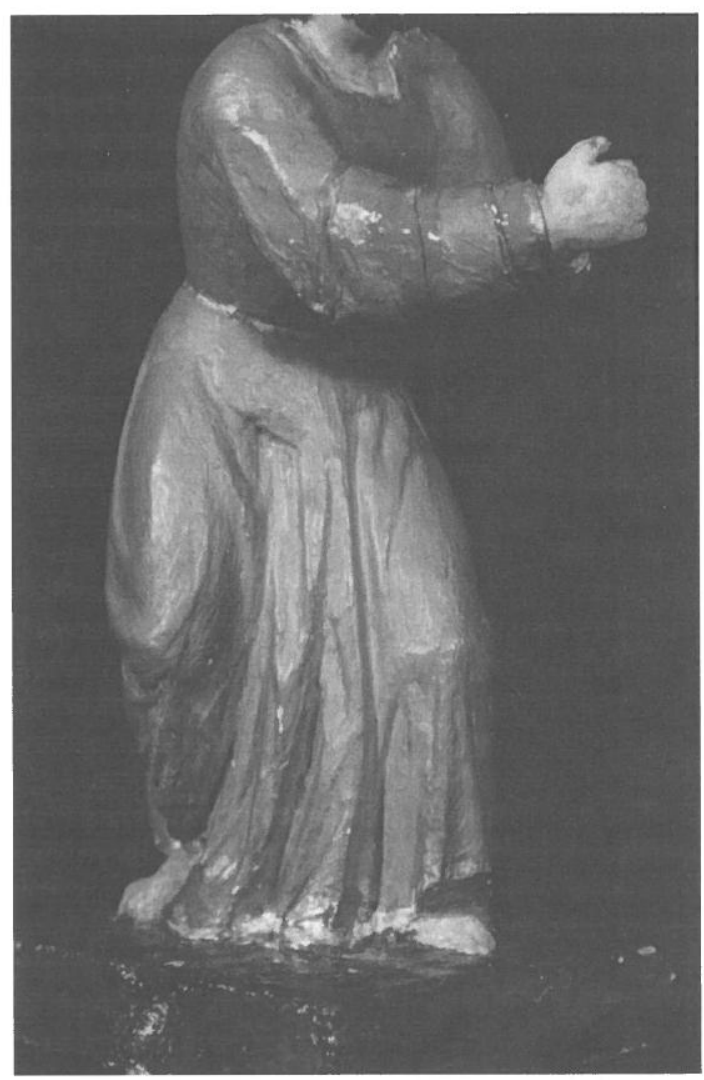

13. Anónimo, seguidor de Rojas. Jesús Nazareno (Furruñique). Detalle, siglo XVII. Guadix, Hermandad de Nuestro Padre Jesús Nazareno "El Llavero". Foto: Enrique Gómez Tejada, cedida por la Hermandad de Nuestro Padre Jesús Nazareno

Sin ánimo de agotar el tema, parece oportuno traer a colación algunas secuelas iconográficas de este modelo. Entre ellas resulta interesante citar la pequeña esculturita del Furruñique de Guadix, imagen de Cristo con la cruz a cuestas utilizada en la taza de demanda de limosnas de la Hermandad de Nuestro Padre Jesús Nazareno de aquella ciudad. Aunque habitualmente vestida, se encuentra perfectamente modelada, si bien se aprecian retoques de modelado sobre todo en el torso y brazos, además de encontrarse completamente repintada. Sin embargo, el ritmo compositivo es muy cercano al del modelo analizado, con el pronunciado arco de piernas y violento giro hacia el exterior del pie derecho, mientras el torso inclinado se gira levemente hacia el lado contrario (FIG. 13). El modelado de la túnica en torno a los muslos y la rodilla resulta generoso de volúmenes para marcar la vehemencia de la zancada e incluso la caída suave y sinuosa en su extremo inferior de los pliegues de la misma procede igualmente de una lectura atenta del modelo de Rojas, en un momento de amplia difusión del mismo. No hay datos acerca de la cronología de esta imagen, aunque estilísticamente parece corresponder a la primera mitad del siglo XVII. Sobre su aceptación popular resulta elocuente testimonio el hecho de ser utilizada para sus demandas por distintas cofradías, lo que generó una denuncia y pleito en $1695^{41}$.

${ }^{41}$ PÉREZ LÓPEZ, S.: Las Cofradías de Semana Santa en Guadix. La Hermandad del Santo Entierro, desde sus orígenes hasta nuestros días. Guadix, Hermandad Sacramental del Santo Sepulcro, 1999, págs. 43-44. Agradezco a mi antiguo alumno don Antonio Francisco Gabarrón Torrecillas y a la hermandad de Nuestro Padre Jesús Nazareno "El Llavero" y Nuestra Señora de la Consolación, Madre de la Iglesia, de Guadix, propietaria de esta imagen, el interés mostrado hacia este estudio y la amable autorización para publicar la fotografía que acompaña a estas notas. 
La misma línea suscriben contadas versiones posteriores, ya que durante buena parte del siglo XVII el tema iconográfico del Nazareno se vuelve poco frecuente en la escuela granadina para renacer con fuerza en la centuria siguiente. Además, son escasas las imágenes desde inicios del Seiscientos que no se realizan para vestir. Entre esas pocas muestras se encuentra la imagen de Jesús Nazareno de la parroquia de Maracena (Granada), correcta de proporciones y modelado, de talla profunda y equilibrada y expresiva composición. Rareza iconográfica resulta el hecho de portar la cruz sobre el hombro derecho. Los estofados de la túnica y la melena natural pueden ser originales, pero no se ocultan repintes y quizás retoques de talla que merman la expresividad del rostro. Pese a todo cabe valorar su sujeción al modelo codificado por Rojas, sólo que con más impulso dinámico, lo que no deja de avalar la vigencia del modelo, como vigoroso punto de partida para un nuevo tipo de imagen devocional naturalista y procesional.

Lo mismo cabría decir de la imagen de Jesús de la Bondad en el Monasterio de San Bernardo de Granada, como tardía manipulación del modelo original. Orozco Díaz la vinculó acertadamente a la estela de Pedro de Mena ${ }^{42}$, algunos de cuyos grafismos se perciben claramente, sobre todo en la configuración fisonómica. Pero adolece de intensidad expresiva y de cierta torpeza de modelado (sobre todo en las manos) en tal modo que no se aproxima siquiera a la calidad y tipo del maestro granadino.

Por último, hubiera resultado pieza clave para la correcta evaluación y comprensión del proceso la desaparecida imagen de Jesús Nazareno para la Cofradía de la Vera Cruz de Motril (Granada), contratada en 1616 por Bernabé de Gaviria ${ }^{43}$. Representa, junto al propio Alonso de Mena en su primera etapa, uno de los mejores intérpretes de la herencia de Rojas. Casi con toda probabilidad, esta imagen debió seguir de cerca el modelo del maestro alcalaíno, lo que lamentablemente no puede corroborarse por la ausencia de testimonios gráficos de la misma.

SOBRE LA PROCEDENCIA DEL NAZARENO DE HUÉTOR VEGA. LA CAPILLA dE JESÚS NAZARENO EN EL CONVENTO DE LOS MÁRTIRES

La documentación exhumada en el Archivo Histórico del Arzobispado de Granada permite identificar definitivamente la señera imagen del Nazareno del Convento de los Mártires con la conservada en Huétor Vega. El origen de este convento se encontraba, como se apuntó más arriba, en una ermita mandada construir por los Reyes Católicos en una colina del Campo de Ahabul, después de los Mártires, legendario paraje de mazmorras y escenario de la entrega de llaves de la fortaleza de la Alhambra según una inscripción mandada realizar al labrar el nuevo convento ${ }^{44}$, como recordatorio del

\footnotetext{
42 OROZCO DÍAZ, E.: "Un Nazareno de Pedro de Mena desconocido", en Miscelánea de Estudios dedicados al profesor Antonio Marín Ocete. Granada, Universidad, 1974, vol. II, págs. 845-850.

43 PEREGRINA PALOMARES, M.: "El contrato de hechura de un Nazareno de Bernabé de Gaviria para Motril”, Cuadernos de Arte de la Universidad de Granada, 31, Granada, 2000, págs. 87-93.

${ }_{44}$ Trascripción de la misma en BARRIOS ROZÚA, J. M.: Reforma urbana y destrucción del patrimonio histórico en Granada. Ciudad y Desamortización. Granada, Universidad-Junta de Andalucía, 1998, pág. 351, nota 269. Ofrece, además, una descripción de lo que se ha podido averiguar
} 
martirio de cristianos en época musulmana. Se trataba de una paraje agreste, no sólo extraurbano sino incluso perteneciente a una jurisdicción independiente de la ciudad como era la capitanía de la Alhambra. Su alcaide, el Conde de Tendilla, interesado en reforzar la «dotación» de su jurisdicción, vio con buenos ojos la solicitud de fray Baltasar de la Cruz, prior de los carmelitas descalzos instalados provisionalmente en la calle Gomérez, y consiguió la cesión de la ermita a esta comunidad conventual en $1573^{45}$

Durante el priorato de San Juan de la Cruz (1582-1588) se mejoraron en parte las deficientes infraestructuras del lugar, entre ellas el abastecimiento de agua, con la construcción de un acueducto y un gran estanque. No obstante, su capacidad seguía siendo insuficiente, por lo que, cuando las condiciones económicas lo hicieron posible, se construyó nuevo convento entre 1614 y 1620, con la participación activa de los mismos frailes en su fábrica material. La antigua ermita pasó a ser sala de capítulo conventual y las pinturas del retablo, donadas por los Reyes Católicos y atribuidas a Juan Ramírez, se colocaron en el altar mayor de la misma iglesia, pasando con la Desamortización al Museo de Bellas Artes ${ }^{46}$.

Distintos testimonios gráficos y escritos permiten colegir una iglesia de planta en cruz latina - "templo vistoso y agradable" al decir de Jorquera ${ }^{47}$-, con una sola nave, cúpula sobre el crucero y una capilla octogonal, apilastrada al exterior, adosada al brazo izquierdo del crucero ${ }^{48}$ (FIG. 14). Por el número de imágenes que cita el inven-

sobre este convento y un relato pormenorizado de sus avatares tras la exclaustración de 1835 . Por otro lado, el discurso ideológico de la Granada contrarreformista, obsesionado por los orígenes cristianos de la ciudad, reitera datos y testimonios acerca del emblemático espacio de los martirios: cfr. ANTOLÍNEZ DE BURGOS, J.: Historia eclesiástica de Granada. Ed. de Manuel Sotomayor Muro. Granada, Universidad, 1996, pág. 126 (ms. de 1609-1610); BERMÚDEZ DE PEDRAZA, F.: Historia eclesiástica de Granada. Granada, por Andrés de Santiago, 1638 —ed. facsimil en Granada, Universidad-Don Quijote, 1989 -, fol. 261 vto. De estos testimonios se hace eco SANTA MARIA, F.: Reforma de los Descalços de Nuestra Señora del Carmen de la primitiva observancia. Hecha por Santa Teresa de Jesús en la antiquísima Religión fundada por el Gran Profeta Elías. Madrid, Diego Díaz de la Carrera, 1644, t. I, págs. 405-406.

${ }^{45}$ SANTA MARÍA, F.: Reforma de los Descalços..., págs. 351 y 401-430.

${ }^{46}$ Bermúdez de Pedraza las enumera (Historia eclesiástica..., fol. 261 vto.): "en medio estava Christo Crucificado, como cabeça de los mártires, y San Pedro puesto en cárcel y cadenas (...), San Juan Bautista degollado, San Sebastián, y San Marcelo Papa en el martirio, San Estevan apedreado, San Hermenegildo Príncipe de España, dando la vida por la Fe Católica, y los dos frayles Franciscos por predicarlas a los infieles". Según nota manuscrita de Gómez-Moreno Martínez, el centro lo ocupaban el Calvario, un Descendimiento y el martirio de los franciscanos, siendo de menor tamaño y colaterales las demás (citado por QUESADA DORADOR, E.: "El Carmen de los Mártires. Jardín de Granada”, en El Carmen de los Mártires. Jardín de Granada. Granada, Ayuntamiento de Granada-Caja de Granada, 2002, pág. 20).

${ }^{47}$ Extraña que lo refiera como "labrado a lo moderno", término con que se suele aludir al gótico, como reiteradamente usa al comentar templos erigidos en los primeros tiempos de la conquista castellana (HENRIQUEZ DE JORQUERA, F:: Anales de Granada, pág. 240). No parece lógico que se quisiera referir a la primitiva ermita, que sí pudo ser de ese estilo.

${ }^{48}$ Por extenso, con referencias gráficas, en BARRIOS ROZÚA, J. M.: Reforma urbana..., pág. 351 . 


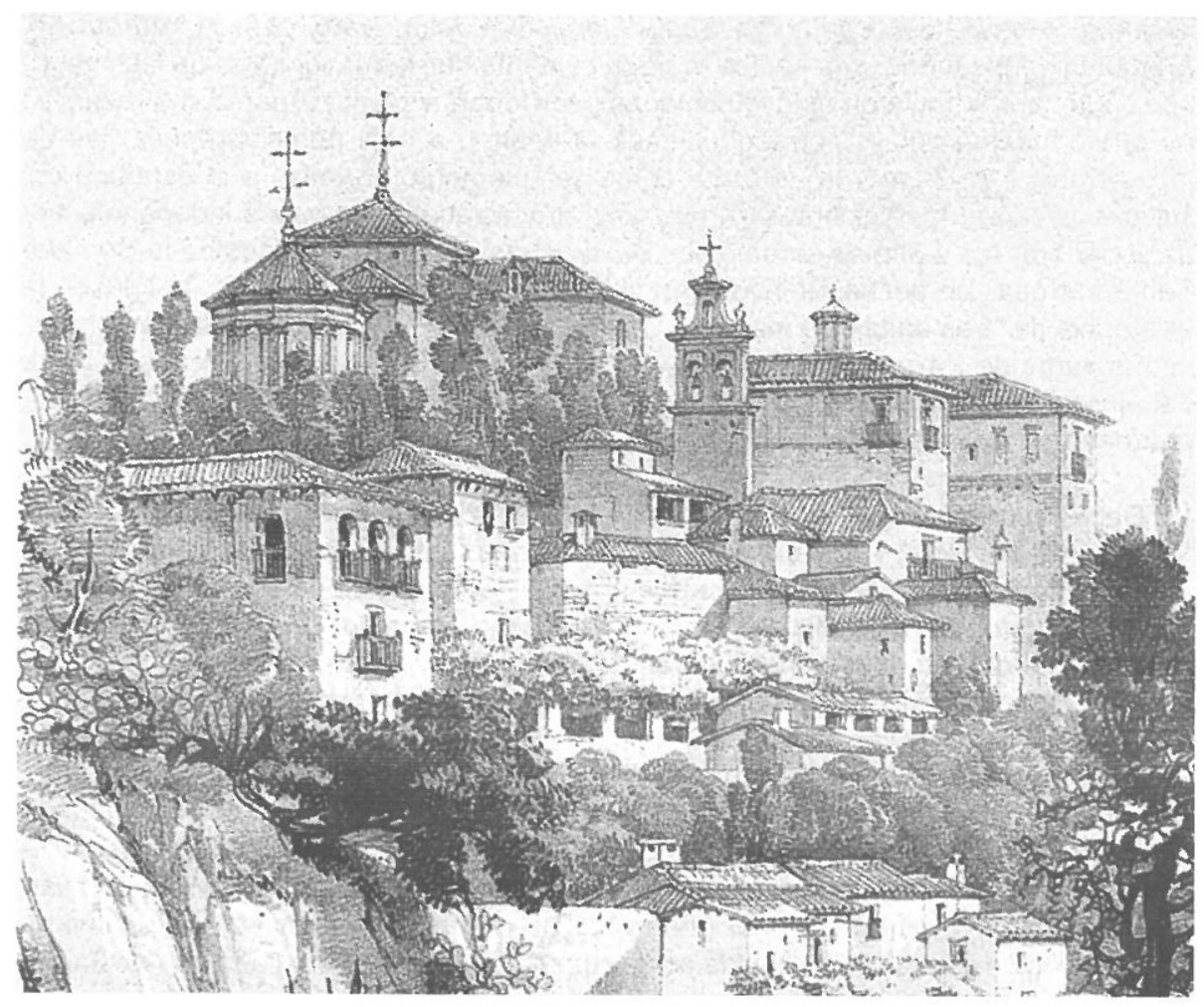

14. Louis Haghe sobre dibujo de George Vivian. "Granada. Convent of the Martyrs, and Sierra Nevada". Detalle, 1838

tario de la Desamortización ${ }^{49}$ en la capilla de Jesús Nazareno e incluso por el orden en que se describen altares y capillas en el mismo parece más que probable que ese cuerpo octogonal correspondiera a la capilla de esta advocación ${ }^{50}$. A tenor del citado inventario, la presidía un retablo dorado, probablemente barroco, con la imagen del Nazareno "con su cruz corta [esto es, de capilla, con el stipes cortado para caber en la hornacina] y cortina morada y frontal de madera". A este retablo principal debieron franquearle otros dos altares correspondientes a Santa Teresa y la Virgen de los Dolores: "Un altar y nicho donde se halla colocada Santa Teresa con puerta de cristales (...) y el altar con frontal de ule". Se completaba el conjunto de la capilla, siempre según el mismo inventario, con otros cuatro nichos - ya no se cita altar- con las imágenes de

\footnotetext{
${ }^{49}$ Archivo Histórico del Arzobispado de Granada (A.H.A.Gr.), leg. 195-V, documentación manejada por gentileza de la doctora María Luisa García Valverde.

${ }^{50}$ Así ya lo ha señalado PADIAL BAILÓN, A.: "La capilla de Jesús Nazareno de Granada", en Hora Nona. Revista de Semana Santa granadina. Granada: APL, 2001, págs. 2-4.
} 
la Beata María de la Encarnación, Santa Elena, San Juan Evangelista y la Verónica ${ }^{51}$. Aunque ninguna fuente lo respalde, parece evidente que la mayor parte de las imágenes de la capilla debieron estar vinculadas a la Cofradia: Santa Elena como recuerdo de sus orígenes, quizás correspondiendo la imagen a esta primitiva época; las de la Dolorosa, San Juan y la Verónica como complemento narrativo a la estampa del Nazareno, quizás participantes en prácticas procesionales en pasos independientes para celebrar las teatrales ceremonias de "encuentro» características de la Semana Santa barroca. De hecho, el inventario cita en el "almacén de útiles $\mathrm{p}^{\mathrm{a}}$. la Iglesia" la existencia de "tres andas de madera (...), cuatro orquillas de madera para las andas; cuatro varas de Palio también de madera (...)". Lo que con certeza sí formaba parte del ajuar procesional del Nazareno es "una cruz de concha con su caja de madera", guardada en el oratorio de la sacristía.

Debe recordarse que, al menos desde el siglo XVIII, la imagen poseía túnica de tela (quizás bordada) y melena natural, postizos propios del Barroco tardío que probablemente fueron los causantes de que un espectador decimonónico como el Conde de Maule no reparara en ella al visitar la iglesia. Sin embargo, el mismo viajero es la única fuente que atribuye las esculturas del retablo mayor ("cuatro santos de cuerpo entero y otro de medio", según el inventario de Desamortización, además de la Virgen de Carmen) como obras de Rodrigo Moreno, presunto maestro de Pablo de Rojas ${ }^{52}$, valiosa referencia en un templo donde se encontraba una imagen, la del Nazareno, atribuida con fundamento al escultor alcalaino. Otro dato que cabe colegir a tenor del citado inventario es que aunque desde la segunda mitad del siglo XVII escasean las noticias de la Cofradía de "las Cruces de Santa Elena", como se la conocía popularmente, siguió ocupando un lugar preferente en el templo conventual, seguramente como devoción alentada y protegida por la comunidad de carmelitas descalzos. Quizás sus prácticas procesionales cesaran con el tiempo o se redujeran a los aledaños del convento, que en el siglo XVIII pasa a la jurisdicción ordinaria de la ciudad al desaparecer la capitanía de la Alhambra. Pero pervivió en el tiempo el conjunto de imágenes relacionadas con esta devoción. Si bien esta estrecha comunión con la comunidad carmelita sostuvo a esta corporación nazarena, también significó su definitiva extinción, si es que no había desaparecido ya, con la exclaustración. Lo prueba el hecho de que no hubo hermandad que reclamara las imágenes y enseres para trasladarse

${ }^{51}$ En el cuerpo de la iglesia, además de la Capilla de Jesús Nazareno, se mencionan las de los Santos Mártires (con las imágenes de Nuestra Señora la Desagraviada o del Socorro, San Cosme y San Damián, y dos lienzos con los martirios de estos santos) y del Santo Cristo (con dos altares, correspondientes al Crucificado y a San Juan de la Cruz), y los altares de Nuestra Señora del Sepulcro, San Miguel y San José, mientras que el altar mayor lo presidía un retablo con la Virgen del Carmen y varios santos y "un cuadro grande encima del retablo, de los Santos Mártires San Cosme y San Damián” (A.H.A.Gr., leg. 195-V). Intencionadamente en el inventario publicado en el Boletín Oficial de la Provincia (18 y 25 de julio de 1838) no se citan ni imágenes ni retablos, cuyo destino era otro. ${ }_{52}$ CRUZ Y BAHAMONDE, N. (Conde de Maule): Viaje de España..., pág. 268. Es éste un grueso problema historiográfico, aún por alumbrar. A Rodrigo Moreno ya lo cita Bermúdez de Pedraza ( $A n$ tigüedad y excelencias de Granada. Madrid, por Luis Sánchez, 1608, pág. 133), pero el primero que lo supone maestro de Pablo de Rojas será Ceán Bermúdez (Diccionario histórico de los más ilustres profesores de las Bellas Artes en España. Madrid, Imprenta de la Viuda de Ibarra, 1800, t. III, pág. 197), quien ya reconocía la escasa memoria conservada de las obras de este artista: "sus obras estarán en aquella ciudad (Granada) atribuidas a otros profesores”. 


\section{Anónimo. San Juan de la Cruz, segunda mitad del siglo XVII. Granada, Convento de San José (Carmelitas Descalzas)}

a otro templo, como ocurrió con otras asociaciones devocionales de seglares ${ }^{53}$.

Así lo corrobora el destino de las imágenes referidas. En abril de 1836 el párroco de Huétor y Cájar presentaba sucesivas peticiones para solicitar las imágenes del Nazareno, la Virgen de los Dolores y el Crucificado, con el ajuar de las primeras y, más tarde, la Virgen del Carmen con elementos de adorno de su camarín, además de otros enseres. Evidentemente no se valoraban estas imágenes con los criterios de excelencia artística que hoy manejamos, lo que justifica el hecho de que esta petición y concesión fueran relativamente tardias, cuando habian sido solicitadas y entregadas otras imágenes como las de Santa Teresa, San José y San Juan de la Cruz de tamaño natural, y otras cinco pequeñas correspondientes a San Cosme, San Damián, Nuestra Señora del Sepulcro, Inmaculada Concepción y San Pedro de Alcántara para la parroquia de San Cecilio en febrero de 1836 —además del órgano y objetos litúrgicos_, o las de San Miguel, Nuestra Señora del Socorro - o la Desagraviada- y la Concepción pequeña de la sacristía para la iglesia del lugar de Agrón en el mismo mes. Y no sería el último destino de algunas de ellas; puede asegurarse al menos en el caso de la

\footnotetext{
${ }^{53}$ La Hermandad del Cristo de San Agustín de los agustinos calzados, la de Nuestra Señora de Gracia de los trinitarios descalzos, la de Nuestra Señora de la Soledad y Entierro de Cristo de los carmelitas calzados o la Principal Hermandad de la Purísima Concepción de San Francisco Casa Grande, entre otras.
} 
imagen de San Juan de la Cruz, hoy en el convento de carmelitas descalzas de San José de Granada ${ }^{54}$ (FIG. 15), adonde fue entregada por el párroco de San Cecilio en 1842 junto a las de San Elias y San Eliseo. Otros templos se beneficiaron de este expolio: al convento de los Ángeles de Granada se le concedieron un cáliz de plata y distintos enseres litúrgicos y de mobiliario, mientras que las dos campanas recalaron en la parroquia de Restábal, en el Valle de Lecrín. Curiosamente se había solicitado la campana mayor para la parroquia de San Andrés de Granada pero a petición de un cofradía no penitencial, la del Cristo de la Salud, residente en esa parroquia ${ }^{55}$.

Todas las imágenes entregadas al párroco de Huétor Vega permanecen en el templo parroquial de esta localidad. El Crucificado, de época cercana al Nazareno aunque más arcaico y repintado, preside en la actualidad el altar mayor; en tiempos tuvo sudario de tela. Tanto la Virgen de los Dolores, remodelada hace poco por el imaginero Miguel Zúñiga, como la del Carmen, obra de fines del Seiscientos o principios del Setecientos, se encuentran en sendas hornacinas en el cuerpo de la iglesia. Sobre la última puede rectificarse la creencia de que fue adquirida por un parroquiano en una almoneda a mediados del siglo $X I X^{56}$, aunque sí ratificar su procedencia de un convento desamortizado, en este caso el de los carmelitas descalzos de los Mártires. Finalmente el Nazareno luce hoy, tras su reciente restauración, a los pies del templo, restituido en lo posible a su imagen original. Como el Nazareno de las Angustias, hace mucho que dejó de vestir con túnica de tela y, finalmente, la mencionada restauración ha eliminado el otro postizo que más alteraba su primitivo aspecto, su melena de pelo natural, lo que ha requerido remodelar la cabellera sobre modelos del mismo Rojas. En cuanto al ajuar procesional de la imagen, la cruz de concha que cita el inventario bien pudiera ser la misma conservada en esta parroquial, sobria en cuanto a decoración pero rica en cuanto al material que la forma, sin las aplicaciones de orfebrería al uso en piezas barrocas de este género en otros lugares de Andalucia ${ }^{57}$.

\section{CONCLUSIÓN}

Los análisis que preceden pretenden alumbrar algo más ese complejo proceso de transición al naturalismo en la escultura andaluza a través de un ejemplo concre-

\footnotetext{
${ }^{54}$ Cfr. AA. VV.: Iconografía y arte carmelitanos, pág. 68.

55 Todos los datos proceden del expediente diocesano formado en la exclaustración de este convento, ya citado (A.H.A.Gr. leg. 195-V). Resulta curioso el diferente procedimiento empleado en cada caso: las parroquias de San Cecilio y de Huétor Vega estuvieron representadas por sus respectivos párrocos; en los casos de Agrón y Restábal, sin embargo, las peticiones las elevaban vecinos particulares, a las que se une la presentada por la citada hermandad de la parroquia de San Andrés de Granada.

${ }^{56}$ GUERRERO RUIZ, A. J.: “19. Virgen del Carmen”, en Huétor Vega. V Centenario..., pág. 104.

${ }^{57}$ La documentación manejada no cita expresamente que se entregara también esta cruz. Sin embargo, la conservada en la parroquia de Huétor Vega, recubierta con placas de carey, cumple con lo descrito en el inventario de la Desamortización y sus medidas $(242 \mathrm{~cm}$ el stipes y $168 \mathrm{~cm}$ el patibulum) resultan adecuadas a la imagen que describimos. Una cruz de este tipo, no obstante, se conserva en la clausura del convento de carmelitas descalzas de Granada, aunque puede pertenecer a la imagen del Nazareno que se encuentra en el coro alto del mismo convento.
} 
to, el Nazareno del convento de los Mártires de Granada y el tipo iconográfico que representa, desde la óptica de la gestación de un nuevo tipo de imagen religiosa de carácter procesional. Distintos parámetros ideológicos, espirituales, estéticos y aun exigencias históricas se dan cita en el desarrollo del proceso. A la luz de los ejemplos examinados parece evidente que el tipo de imagen consagrada por Rojas supone una reorientación de la plástica tras las alternativas emocionales y expresivas del tercio central del Quinientos. Se impone una reflexión ética sobre un patrón estético basado en la espiritualidad y la expresividad contenida que se manifiesta a través de un noble sentido de la forma —-herencia clásica-, de la sinceridad y espontaneidad expresivas de honda humanidad - acento naturalista - o de la contención en el movimiento aunque sin resultar estáticas, todo ello fruto de una nueva óptica en la percepción de la imagen artística, sin caer en lo vulgar y prosaico del realismo castellano o de algunos pintores del primer naturalismo, por ejemplo.

En Granada especiales circunstancias históricas derivadas del conflicto morisco aliñan el proceso. Pero también es indudable la considerable influencia que sobre él ejerce la literatura mística. La imagen del Nazareno de los Mártires, en concreto, posee unos matices compositivos y expresivos que difieren en sensibilidad de otros ejemplos del mismo tipo iconográfico y atribuidos también a Pablo de Rojas. Y si nuestra hipótesis es correcta, esos matices están relacionados con la influencia más o menos directa del místico reformador carmelita San Juan de la Cruz. Alguien tan relacionado con el mundo de la imagen religiosa, tanto mental como plástica y tangible, conocedor del oficio imaginero, que se expresa con criterios estéticos en sus escritos, sabedor del potencial comunicativo de las imágenes pero también de las limitaciones que deben imponerse a las mismas, se encontraba en inmejorable posición para ayudar a moldear un nuevo tipo de imagen religiosa, paso decidido - quizás sin pretenderlo - hacia el naturalismo en los modos plásticos y, por ende, innovador en la gestación del género de la escultura procesional.

El instinto plástico de Pablo de Rojas hace el resto. La imagen exenta representa unos problemas plásticos y expresivos diferentes, fruto de una nueva concepción de la imagen religiosa atenta al espacio en que se desenvuelve y actúa. Ofrece una naturaleza comunicativa más vehemente, como había expresado previamente la literatura ascética y mística, y que se convierte en un cauce devocional de rápida difusión popular, primero a través de imágenes sosegadas y serenas, después en formas de expresividad más exaltada, que imprimen la viveza de una escena teatral. Ello supone el espaldarazo definitivo para la escultura procesional. Frente a lo limitado de los elementos icónicos en los orígenes de las hermandades penitenciales en sus prácticas penitenciales, la incorporación plena de las mismas en el último tercio del siglo exige la revisión de su concepto estético, desde presupuestos escenográficos - teniendo en cuenta el dilatado espacio de su contemplación-y expresivos nuevos.

En este sentido, imágenes como las arriba estudiadas se encuentran en la base de la creación del tipo del Nazareno procesional para toda Andalucía. Y, cuando menos, queda claro lo complejo de este proceso de aquilatación del naturalismo en la plástica española en el camino del Barroco y la influencia de los místicos en su gestación, siendo hermosa referencia, aún diríamos que clave, el impresionante Nazareno de los Mártires. 


\section{APÉNDICE DOCUMENTAL}

Expediente de desamortización del Convento de los Mártires de Carmelitas Descalzos de Granada. Peticiones de imágenes y objetos litúrgicos.

Archivo Histórico del Arzobispado de Granada, legajo 195-V

\section{INSTANCIA DEL PÁRROCO DE HUÉTOR VEGA SOLICITANDO IMÁGENES Y} ENSERES DEL CONVENTO DE LOS MÁRTIRES. 1836, ABRIL, 12.

\section{"Excmo. Señor Arzobispo}

D. Antonio del Villar, Cura Propio de las Ygls Parroq $^{\text {s }}$ de Huétor y Caxar, a V.E. con el devido respeto dice: questa Iglesia de Huétor es sumamente pobre y carece de las principales Ymágenes y otras cosas por lo $\mathrm{q}^{\mathrm{e}}$

A V.E. Suplica se digne concederle las Ymágenes de Jesús Nazareno, Jesús Crucificado y Maria $\mathrm{S}^{\mathrm{ma}}$. de los Dolores, dos lámparas de azófar, las tres sillas del Presbiterio, seis jarras de oja de lata, las gradas del monum ${ }^{\text {to }}$, la puerta de cristales del camarin de la Virgen, la pedana ( $\mathrm{sic}$ ) donde se coloca la custodia, con toda la ropa, adornos e insignias de las referidas Ymágenes; todo ello reside y pertenece al Combento de los $S^{\text {tos }}$ Mártires: favor y gracia q espera merecer de la bondad y zelo de V.E. cuya importante vida guarde $D^{\mathrm{s}} \mathrm{m}^{\mathrm{s}} \mathrm{a}^{\mathrm{s}}$. Huétor Vega y Abril, 12 de 1836.

Antonio del Villar (rúbrica)"

(Al margen) "Granada, 16 de Abril de 1836

El Comisionado Ecco. en el Conv ${ }^{\text {to }}$ suprimido de los Mártires informará si esisten los efectos que se reclaman en esta esposición. Lo decretó y rubricó S.E. el Arzobispo mi $S^{\circ}$., lo que certifico.

(rúbrica del arzobispo)

Dr. Tenorio (rúbrica)"

(Al margen) "Exmo. Señor. El Cura propio de la Parroq' de $\mathrm{S}^{n}$ Cecilio dice que efectivamente existen los efectos $q^{\text {e }}$ se reclaman en la Yglesia del Con ${ }^{\text {to }}$ suprimido de carmelitas descalzos de esta ciudad. Dios gue la importante vida de V.E. $\mathrm{m}^{\mathrm{s}} \mathrm{a}^{\mathrm{s}}$. Granada, 18 de Abril de 1836.

José de la Rosa (rúbrica)"

"Granada, Abril 19 de 1836

Concedemos al Cura suplicante los efectos que solicita en la precedente expo- 
sición, dando orden al Comisionado en el Conv to de Carmelitas Descalzos para que haga la entrega bajo recibo que remitirá original para unirlo a su expediente. Lo decretó y rubricó S.E. el Arzobispo mi Sr. de que certifico.

(rúbrica del arzobispo)

Dr. Tenorio (rúbrica)"

\section{NUEVA INSTANCIA DEL PÁRROCO DE HUÉTOR VEGA SOLICITANDO MÁS PIEZAS DEL CONVENTO DE LOS MÁRTIRES. 1836, ABRIL, 24.}

\section{"Emo. Sr Arzobispo de esta Diócesis}

$D^{n}$. Antonio del Villar, Cura Propio de las Ygls Parroq ${ }^{s}$ de Huétor y Caxar, a V.E. con el debido respeto dice: que son dos $\mathrm{Ygl}^{\mathrm{s}}$, y ambas pobres, las $\mathrm{q}^{\mathrm{e}}$ tiene a su cargo y es la causa de seguir molestando la atención de V.E. para adornarlas y dar el debido culto a Dios, por lo que juzga conveniente $\mathrm{q}^{\mathrm{e}}$ se le conceda la Imagen de $\mathrm{N}^{\text {ra }} \mathrm{S}^{\mathrm{ra}} \mathrm{del}$ Carmen con su ropa y todos sus adornos, la que se haya colocada en el camarín del altar mayor, y la de $\mathrm{S}^{\text {ta }}$ Teresa con su puerta de cristales que está en la capilla de Jesús Crucificado y otra puerta de cristales qe está en un altar de la capilla donde estaba Jesús de Nazareno ( $\mathrm{sic}$ ), seis escaños, un facistol, tres pares de vinageras de vidrio, docena y media de candeleros de madera, la lámpara de oja de lata de la Capilla del $\mathrm{S}^{\text {to }}$ Cristo y las cortinas del camarin de la virgen del Carmen y cuatro atrileras.

A V.E. Suplica se digne concederle su solicitud de todo lo que pide del extinguido convento de Carmelitas Descalzos, que es donde esiste todo lo relacionado, gracia que espera merecer de V.E. cuya importante vida guarde Dios $\mathrm{m}^{\mathrm{s}} \mathrm{a}^{\mathrm{s}}$. Huétor Cajar y Abril, 24 de 1836.

Antonio del Villar (rúbrica)"

(Al margen) “Granada y Abril 26 de 1836.

El Comisionado Ecco. en el Convento suprimido de los Mártires informará si esisten los efectos que se solicitan en esta esposición. Lo decretó y rubricó S.E. el Arzobispo mi Sor., de que certifico.

(rúbrica del arzobispo)

Dr. Tenorio (rúbrica)"

(Al margen) "Exmo. Sor. Todos estos efectos existen, excepto la puerta de cristales del altar de Jesús Nazareno, porque no tenía, ni creo $q^{\mathrm{e}}$ la ha tenido nunca, en lo $\mathrm{q}^{\mathrm{e}}$ padece equivocación el Sor Cura de Huétor y Cajar. Dios gue a V.E. $m^{s} a^{s}$. Granada, 2 de Mayo de 1836. Exmo. Sor.

José de la Rosa (rúbrica)" 
"Granada y Mayo 7 de 1836.

En vista de la presente exposición y con mérito de lo que resulta de anterior informe concedemos al Cura suplic ${ }^{\text {te }}$ los efectos que solicita del suprimido Convento de Carmelitas Descalzos de esta ciudad, dándole conocimiento y or ${ }^{n}$ al Comisionado para que haga la entrega bajo recibo circunstanciado que remitirá para unirlo a su expediente. Lo decretó y rubricó S.E. el Arzobispo mi Sor. de que certifico.

(rúbrica del arzobispo)

Dr. Tenorio (rúbrica)"

3.RECIBOS DE LAS ENTREGAS DE IMÁGENES Y ORNAMENTOS DE LOS MÁRTIRES AL PÁRROCO DE HUÉTOR VEGA. 1836, ABRIL, 22 Y 1836, MAYO, 14

"He recivido del Sr D" José de la Rosa, Cura propio de la iglesia parroq' del S' San Cecilio de esta Ciudad, como comisionado del Convento de Carmelitas Descalzos los efectos siguientes: las ymágenes de Jesús Nazareno, Jesús Crucificado, María $\mathrm{S}^{\mathrm{ma}}$ de los Dolores con la ropa de ordinario, dos lámparas de ajófar (sic), tres sillones del presviterio, seis jarras de oja de lata, las gradas del Monumento, la puerta de cristales del camarín de la Virgen y una pedana (sic) dorada, y $\mathrm{p}^{\mathrm{a}} \mathrm{q}^{\mathrm{e}}$ sirva de resguardo firmo.

Granada y Abril 22 de 1836 .

Antonio del Villar (rúbrica)"

"He recivido del Señor D. José de la Rosa, Cura propio de la iglesia parroq' del Señor $\mathrm{S}^{n}$ Cecilio de esta Ciudad, los efectos siguientes: la imagen de $\mathrm{N}^{a} \mathrm{~S}^{a}$ del Carmen con la ropa de ordinario y $\sin$ Niño, las tres cortinas con sus baras del camarin, y la repisa; cinco escaños, un facistol, cuatro atrileras, diez y ocho candeleros de madera, una lámpara de oja de lata, tres pares de vinajeras, dos cortinas con sus baras, una de tafetán y otra de mosolina ( $\mathrm{sic}$ ) color de caña, con una puerta de cristales pequeños $\mathrm{q}^{\mathrm{e}}$ pertenecía a la capilla o camarín de $\mathrm{S}^{\mathrm{ta}}$ Teresa en la capilla de Jesús Nazareno. Todo ello del Convento de Carmelitas descarzos (sic) de esta ciudad y $\mathrm{p}^{\mathrm{a}} \mathrm{q}^{\mathrm{e}}$ sirva de resguardo doy y firmo el presente en Granada y Mayo 14 de 1836.

Antonio del Villar (rúbrica)" 